
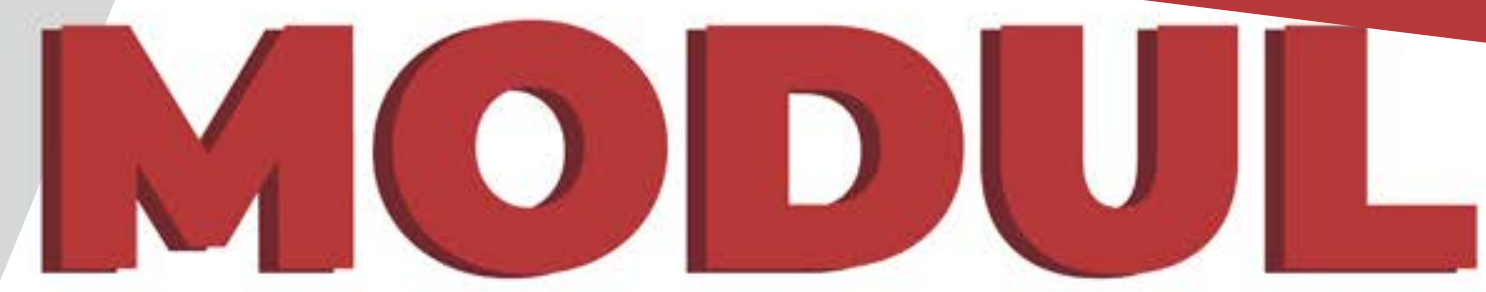

\title{
PENDIDIKAN KESEHATAN DAN PEMENUHAN GIZI SEIMBANG PADA REMAJA PUTRI
}

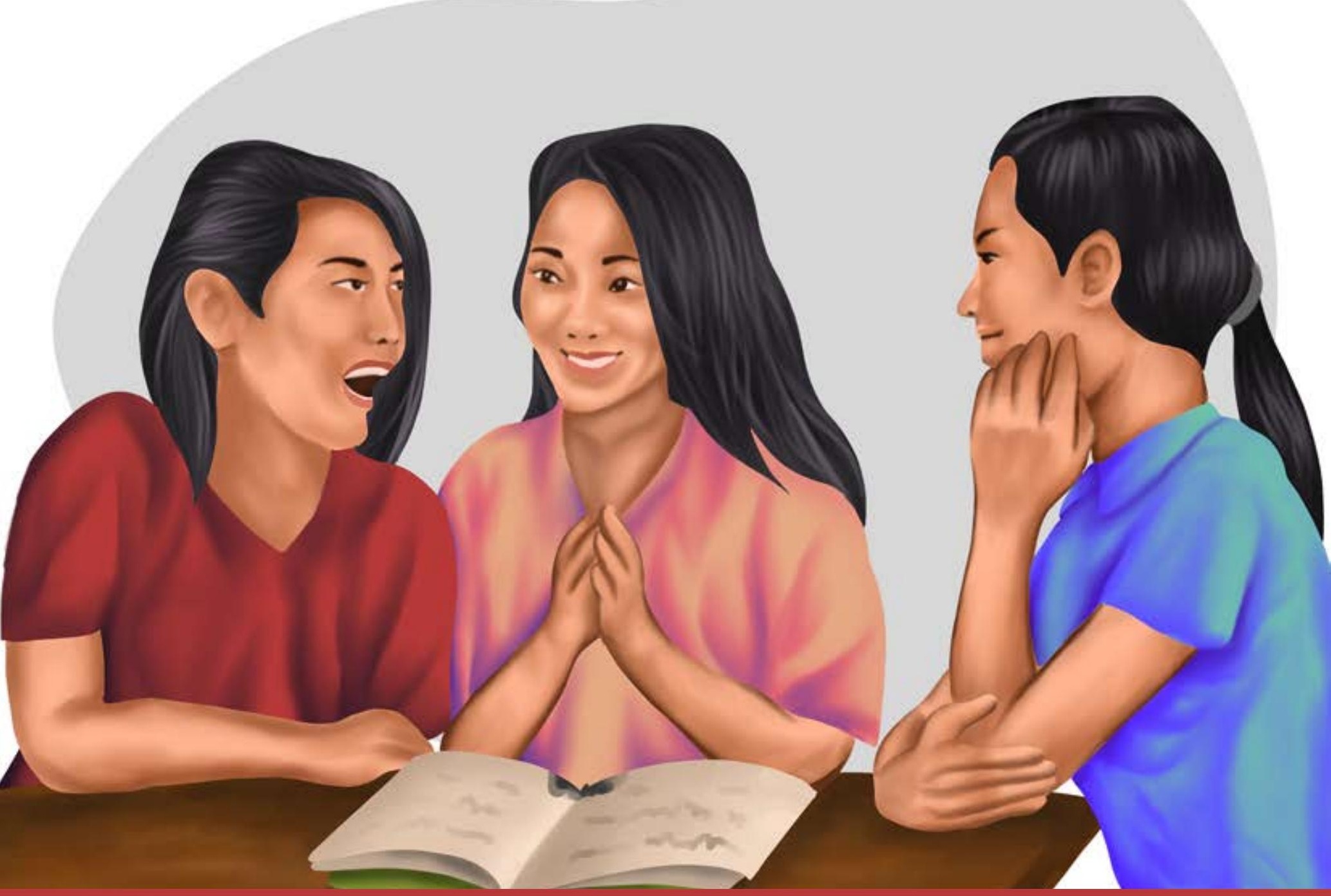

Departemen Kesehatan Masyarakat dan

Kedokteran Pencegahan

Fakultas Kedokteran Universitas Udayana 2021 


\title{
MODUL \\ PENDIDIKAN KESEHATAN DAN \\ PEMENUHAN GIZI SEIMBANG \\ PADA REMAJA PUTRI
}

\author{
Penulis: \\ Dinar Saurmauli Lubis, S.KM, MPH, PhD \\ Dr. Kadek Tresna Adhi, S.KM, M.Kes \\ Dr. dr I Gede Ngurah Indraguna Pinatih, M.Sc.Akp, Sp.GK \\ I Gusti Agung Agus Mahendra, SKM. MPH
}

Departemen Kesehatan Masyarakat dan Kedokteran Pencegahan

Fakultas Kedokteran Universitas Udayana

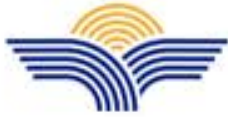

PENERBIT

PANUDUH ATMA WARAS

Jl. ByPass Ngurah Rai Nomor: 888 xx, Denpasar, Bali - Indonesia

(0361) 6209990

$(+62) 82236180725$

info@baswarapress.com

panuduhatmawaras@gmail.com 


\title{
MODUL \\ PENDIDIKAN KESEHATAN DAN PEMENUHAN GIZI SEIMBANG \\ PADA REMAJA PUTRI
}

\author{
Penulis : \\ Dinar Saurmauli Lubis, S.KM, MPH, PhD \\ Dr. Kadek Tresna Adhi, S.KM, M.Kes \\ Dr. dr I Gede Ngurah Indraguna Pinatih, M.Sc.Akp, Sp.GK \\ I Gusti Agung Agus Mahendra, SKM. MPH
}

ISBN (PDF) : 978-623-97473-8-1

Copyright @ Juli 2021

Hak Cipta dilindungi oleh Undang-Undang. Pertama kali diterbitkan di Indonesia dalam Bahasa Indonesia oleh PANUDUH ATMA WARAS. Penggunaan material dalam karya ini diatur dalam Lisensi Publik Creative Commons 4.0 Atribusi-NonKomersial-TanpaTurunan (CC-BY-ND). Pengguna dapat mengutip konten dalam karya ini dengan memberi kredit yang sepantasnya kepada penulis asli karya ini. Dilarang menggunakan karya ini untuk kepentingan komersial dalam bentuk apapun. Dilarang mengubah dan menyebarluaskan isi karya ini dalam bentuk apa pun tanpa izin tertulis dari penulis.

\section{PENERBIT \\ PANUDUH ATMA WARAS}

JI. ByPass Ngurah Rai Nomor: 888 xx, Denpasar, Bali - Indonesia

(0361) 6209990; (+62)82236180725

info@baswarapress.com

panuduhatmawaras@gmail.com 


\section{UCAPAN TERIMA KASIH}

Selama menyusun modul ini tim penulis telah banyak mendapat bantuan dan dukungan dari berbagai pihak baik secara langsung maupun tidak langsung. Untuk itu, dengan segala kerendahan hati, tim penulis bermaksud untuk menyampaikan ucapan terima kasih yang sebesar-besarnya kepada semua pihak yang turut membantu, khususnya:

1. Dekan Fakultas Kedokteran Universitas Udayana beserta jajarannya.

2. Tim East Bali Proverty Project (EBPP).

3. Para validator modul. 


\section{KATA PENGANTAR}

Permasalahan gizi pada remaja merupakan salah satu permasalahan kesehatan masyarakat yang sejak lama di temukan di Desa Ban, Kabupaten Karangasem, Provinsi Bali. Intervensi untuk mengatasi permasalahan gizi pada kelompok remaja ini telah dilakukan bersamaan dengan intervensi pada kelompok rentan lainnya seperti ibu hamil, ibu baduta dan baduta. Namun intervensi yang ditawarkan masih mempunyai beberapa kelemahan seperti masih bersifat individual hanya pada kelompok sasaran. Oleh karena itu perlu sebuah inovasi intervensi gizi yang menggunakan pendekatan yang inovatif dengan melibatkan peer atau teman sebaya dalam upaya mengatasi permasalahan gizi ini.

Intevensi ini dinamai 'penanggulangan permasalahan gizi berbasis keluarga' yang dikembangkan berdasarkan pentingnya peran keluarga dalam meningkatkan kesehatan keluarga. Intervensi ini menyasar kelompok ibu hamil, ibu baduta dan baduta serta remaja. Dalam hal sasaran remaja, pendekatan menggunakan pengaruh teman sebaya atau peers. Intervensi yang dilakukan diharapkan dapat meningkatkan pengetahuan, sikap dan perilaku mengenai asupan gizi seimbang pada remaja putri. Modul ini disusun sebagai bagian dari intervensi dimaksud dengan tujuan untuk meningkatkan kemampuan dan keterampilan petugas lapangan/fasilitator dalam memberikan edukasi gizi seimbang pada remaja.

Kami sangat berterima kasih terhadap semua pihak yang telah membantu dalam penyusunan modul ini dan pihak-pihak yang mengapresiasi dan menggunakan modul ini sebagai acuan dalam pelaksanaan intervensi gizi dengan pendekatan keluarga. Kami menyadari bahwa masih terdapat berbagai kekurangan dalam modul ini, sehingga kritik dan saran pengguna modul sangat diharapkan. Harapan kami modul ini bermanfaat bagi petugas lapangan/fasilitator dalam rangka meningkatkan keterampilan dan kepercayaan diri saat melaksanakan dan memberikan materi pada kelompok sasaran di lapangan.

Tim Penulis 


\section{DAFTAR}

ISI

SAMPUL

PENULIS

LEMBAR ISBN

UCAPAN TERIMAKASIH

KATA PENGANTAR

DAFTAR ISI

DAFTAR GAMBAR

Pengantar Modul

Latar Belakang

Tujuan Penyusunan Modul

Sasaran Penyusunan Modul

Silabus Modul Pendidikan Gizi Pada pada Remaja Putri

Materi Modul

Sesi pertemuan 1: Permasalahan gizi pada remaja putri

Pengaruh Gizi Remaja dalam Siklus Kehidupan

Masalah Gizi Remaja: Anemia Defisiensi Zat Besi

Masalah Gizi Remaja: Kekurangan Energi Kronis

Daftar pertanyaan dan jawaban

Sesi pertemuan 2: Citra tubuh yang Sehat dan Tepat

Konsep Citra tubuh

Studi kasus: Citra tubuh dan pengukuran indeks masa tubuh

Sesi pertemuan 3: Diet Sehat dan Gizi Seimbang pada Remaja

Diet sehat dan seimbang pada remaja

Studi kasus: pengaruh media dalam pemilihan makan pada remaja

Referensi

Protokol Kesehatan selama implementasi intervensi pendidikan kesehatan dan pemenuhan gizi seimbang pada remaja putri 


\section{DAFTAR GAMBAR}

Gambar 1. Pengaruh gizi remaja dalam siklus kehidupan $\quad 18$

Gambar 2. Gejala Anemia

Gambar 3. Dampak dan pencegahan Anemia

Gambar 4. Penyebab, dampak dan pencegahan KEK pada remaja putri

Gambar 5. Pengertian dan faktor yang mempengaruhi citra tubuh

Gambar 6. Dampak dan gangguan makan karena pengaruh citra tubuh negatif

Gambar 7. Tips cara menanggulangi citra tubuh negatif

Gambar 8. Tumpeng gizi seimbang untuk remaja

Gambar 9. Pesan gizi seimbang untuk remaja putri 


\section{PENGANTAR \\ MODUL}

\section{Latar Belakang}

Indonesia saat ini hingga tahun 2030 sedang berada pada bonus demografi dimana jumlah penduduk produktif lebih tinggi dibandingkan dengan penduduk non produktif. Bonus demografi ini menjadi peluang untuk pembangunan bangsa. Namun tantangan utama yang dihadapi oleh Indonesia dalam memanfaatkan bonus demografi ini adalah Pembangunan sumber daya manusia yang berkualitas, sehat, cerdas, dan produktif Pembangunan sumber daya manusia yang sehat dan kuat sejogyanya dimulai dari membangun Kesehatan ibu dan anak. Oleh karena itupembangunan kesehatan berdasarkan rancangan Rencana Pembangunan Jangka Menengah Nasional (RPJMN) periode tahun 2020-2024 memprioritaskan peningkatan status kesehatan ibu dan anak serta peningkatan status gizi di masyarakat (Kemenkes, 2020).

Dalam rangka meningkatkan status gizi dan kesehatan ibu dan anak yang dilahirkannya, maka pemenuhan gizi seimbang harus dimulai pada masa prakonsepsi yang menyasar para calon ibu atau remaja putri. Berdasarkan Riset Kesehatan Dasar (Riskesdas) tahun 2018, secara nasional prevalensi remaja putri usia 13-15 tahun yang sangat pendek dan pendek mencapai 5,3\% dan 19,6\%, secara berurutan. Sementara itu, prevalensi gizi kurang pada kelompok tersebut tercatat sebesar 5,4\%. Untuk kelompok remaja putri usia 16-18 tahun, prevalensi sangat pendek dan pendek sedikit lebih tinggi dibandingkan kelompok usia yang lebih muda yaitu sebesar 3,5\% dan 21,5\%, secara berurutan. Berbanding terbalik dengan prevalensi gizi buruk yang cenderung lebih rendah pada kelompok remaja putri usia $16-18$ tahun yaitu 4,3\% (Kemenkes, 2019a). Selain itu prevalensi kasus anemia pada remaja putri 10-19 tahun mengalami peningkatan berdasarkan Riskesdas tahun 2013 ke 2018 yaitu dari sekitar 31,7\% menjadi 48,9\% (Kemenkes, 2019a). Prevalensi kasus Kekurangan Energi Kronis (KEK) pada remaja putri pun masih dapat dikatakan cukup tinggi yaitu mencapai 36,3\% pada remaja putri usia 15-19 tahun yang tidak sedang hamil (Kemenkes, 2019a).

Di Provinsi Bali, prevalensi sangat pendek dan pendek pada remaja putri mencapai 9,34\% pada kelompok usia 13-15 tahun dan 12,51 pada kelompok usia 16-18 tahun. Sementara itu, prevalensi gizi kurang mencapai $2,49 \%$ dan 3,35\% pada kelompok usia 13-15 tahun dan kelompok usia 16-18 tahun, secara berurutan (Kemenkes, 2019b). Selain itu prevalensi KEK pada remaja putri usia 15-19 tahun yang tidak sedang hamil mencapai sekitar 30\% (Kemenkes, 2019b). Berdasarkan penelitian pendahulan yang dilakukan oleh Departemen Kesehatan Masyarakat dan Kedokteran Pencegahan (KMKP), Fakultas Kedokteran Universitas Udayana yang bekerja sama dengan East Bali Proverty Project (EBPP) pada tahun 2019 di Desa Ban, Karangasem Bali, menemukan bahwa prevalensi gizi kurang pada remaja putri usia 14-19 tahun mencapai 5\% (Lubis et al., 2020). Hal tersebut menunjukkan prevalensi gizi kurang pada remaja cenderung lebih tinggi dibandingkan dengan prevalensi di tingkat provinsi. 


\section{PENGANTAR MODUL}

Yayasan Ekoturin telah melakukan upaya pengembangan masyarakat di Desa Ban sejak tahun 1992, dimana perbaikan status gizi masyarakat menjadi salah satu fokusnya. Upaya upaya yang dilakukan Yayasan Ekoturin meliputi peningkatan ekonomi masyarakat, tingkat pendidikan dan kesehatan dengan melakukan pendekatan yang berbasis posyandu maupun secara individu pada bayi yang menderita gizi buruk. Namun dirasakan bahwa upaya tersebut belum menunjukkan hasil yang cukup maksimal untuk dapat meningkatkan status gizi masyarakat pada kelompok rentan gizi seperti lbu hamil, ibu baduta, baduta dan remaja. Untuk mendukung kegiatan kegiatan yang telah dilakukan selama ini, Yayasan Ekoturin bekerjasama dengan tim peneliti dari Departemen KMKP untuk mengetahui efektifitas dari konsep pendekatan keluarga sebagai salah satu upaya untuk mengatasi permasalahan gizi di Desa Ban. Berbagai data empiris menunjukkan bahwa keluarga sangat berperan dalam menentukan pola asuh dan konsumsi makanan utama pada anak remaja (Utter et al., 2019).Upaya yang dilakukan adalah dengan mengembangkan suatu model edukasi gizi yang menyasar seluruh anggota, namun khusus untuk pendekatan pada remaja, dikembangkan dengan menggunakan pendekatan peers atau teman sebaya. Modul ini disusun sebagai bagian dari intervensi dimaksud dan bertujuan sebagai bahan acuan bagi fasilitator dalam memberikan edukasi gizi pada remaja. Adapun yang menjadi fasilitator adalah staff EBBPP yang telah terlatih untuk memfasilitasi kegiatan edukasi pada masyarakat dan telah memahami permasalahan yang dihadapi oleh masyarakat Desa Ban.

masyarakat, tingkat pendidikan dan kesehatan dengan melakukan pendekatan yang berbasis posyandu maupun secara individu pada bayi yang menderita gizi buruk. Namun dirasakan bahwa upaya tersebut belum menunjukkan hasil yang cukup maksimal untuk dapat meningkatkan status gizi masyarakat pada kelompok rentan gizi seperti lbu hamil, ibu baduta, baduta dan remaja. Untuk mendukung kegiatan kegiatan yang telah dilakukan selama ini, Yayasan Ekoturin bekerjasama dengan tim peneliti dari Departemen KMKP untuk mengetahui efektifitas dari konsep pendekatan keluarga sebagai salah satu upaya untuk mengatasi permasalahan gizi di Desa Ban. Berbagai data empiris menunjukkan bahwa keluarga sangat berperan dalam menentukan pola asuh dan konsumsi makanan utama pada anak remaja (Utter et al., 2019).Upaya yang dilakukan adalah dengan mengembangkan suatu model edukasi gizi yang menyasar seluruh anggota, namun khusus untuk pendekatan pada remaja, dikembangkan dengan menggunakan pendekatan peers atau teman sebaya. Modul ini disusun sebagai bagian dari intervensi dimaksud dan bertujuan sebagai bahan acuan bagi fasilitator dalam memberikan edukasi gizi pada remaja. Adapun yang menjadi fasilitator adalah staff EBBPP yang telah terlatih untuk memfasilitasi kegiatan edukasi pada masyarakat dan telah memahami permasalahan yang dihadapi oleh masyarakat Desa Ban. 


\section{PENGANTAR MODUL}

\section{Tujuan Penyusunan Modul}

Modul ini disusun dengan tujuan utama sebagai buku pedoman bagi fasilitator dalam menyampaikan pendidikan kesehatan dan pemenuhan gizi seimbang pada remaja putri di Desa Ban Karangasem, Bali. Adapun yang menjadi tujuan khusus dari penyusuan modul ini adalah sebagai berikut:

1. Meningkatkan pengetahuan remaja putri tentang permasalahan gizi, citra tubuh dan pemenuhan gizi seimbang selama masa remaja.

2. Membentuk sikap positif terhadap citra tubuh-nya dan konsep pemenuhan gizi seimbang selama masa remaja.

3. Membentuk perilaku pemenuhan gizi seimbang melalui diet yang sehat selama masa remaja.

\section{Sasaran Penyusunan Modul}

Adapun sasaran dari modul ini adalah remaja putri. Remaja putri yang dimaksud adalah remaja putri yang berusia 12-19 tahun, belum menikah dan bertempat tinggal di Desa Ban Karangasem. Pemberian intervensi atau penyampaian materi pada remaja putri dilakukan dengan metode diskusi partisipatif dengan menggunakan pendekatan komunikasi dua arah. Fasilitator yang memberikan intervensi pendidikan kesehatan dan pemenuhan gizi seimbang pada remaja putri adalah petugas kesehatan lapangan dari EBPP yang telah dilatih dan dinyatakan memiliki kompetensi untuk melaksanakan intervensi. 


\section{Silabus Modul Pendidikan Gizi Pada pada Remaja Putri}

Sasaran : Remaja Putri

Pemberi materi : Fasilitator yang telah terlatih

Total durasi : 90 menit

Metode evaluasi : Pre dan post test survei

Materi
Pembelajaran

\begin{tabular}{l}
\multicolumn{1}{c}{ Uraian Materi } \\
dan Permainan \\
Masalah gizi \\
remaja: anemia \\
defisiensi zat besi \\
dan KEK
\end{tabular}

10 menit

Sesi pertemuan 1: Permasalahan gizi pada remaja putri

$\begin{array}{ll} & \text { Metode } \\ & \\ & \text { Diskusi } \\ \text { kelompok } & \text { kecil } \\ & \text { Diskusi } \\ \text { partisipatif } \\ \text { dengan } \\ \text { metode } \\ \text { komuni- } \\ \text { kasi dua } \\ \text { arah }\end{array}$

Permainan:

ATIKA sumber zat besi

\section{Permainan}

\section{0 menit}

Permainan

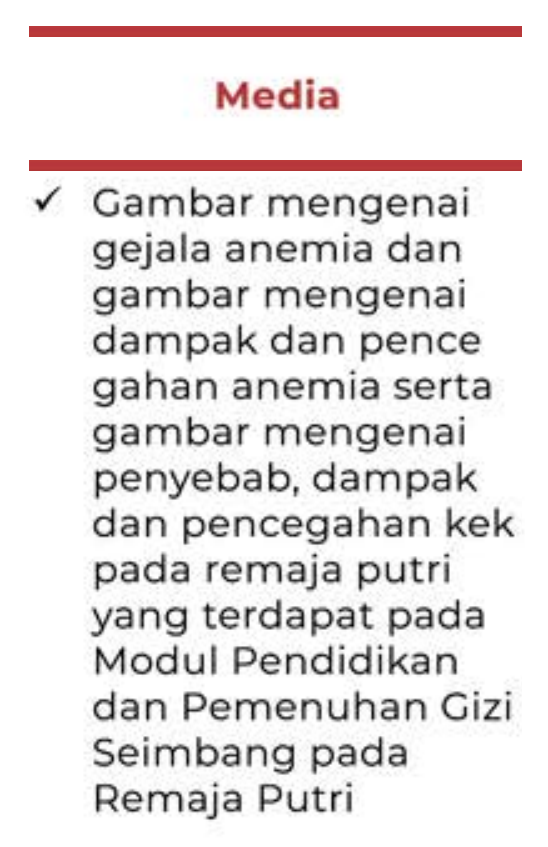

Gambar mengenai gambar mengenai dampak dan pence gahan anemia serta gambar mengenai penyebab, dampak dan pencegahan kek yang terdapat pada Seimbang pad Remaja Putri
EMO DEMO: Demo

Rumpi Sehat O2 ATIKA Sumber Zat Besi, disusun oleh GAIN dan Kementerian Kesehatan, diadaptasi untuk sasaran remaja putri

\section{Keluaran yang diharapkan}

$\checkmark$ Pemahaman remaja putri mengenai permasalahan anemia defisiensi zat besi pada remaja dan KEK, termasuk penyebab, gejala, dampak dan pencegahannya

$\checkmark$ Sikap positif remaja putri dalam mengonsumsi makanan kaya zat besi dan tablet tambah darah (TTD) secara patuh serta menerap kan pola makan yang seim bang dan beragam untuk mencegah anemia dan KEK

$\checkmark$ Perilaku mengonsumsi makanan kaya zat besi dan tablet tambah darah (TTD) secara patuh dan pola makan yang seimbang dan beragam untuk mencegah anemia dan KEK

$\checkmark$ Pemahaman remaja putri mengenai pentingnya asupan zat besi selama masa remaja 


Materi
Pembelajaran

Sesi pertemuan 2:

Citra tubuh yang

Sehat dan Tepat

\section{Uraian Materi dan Permainan}

Review per-

temuan 1

Konsep citra tubuh pada remaja

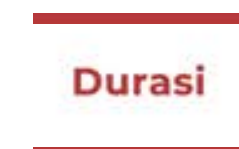

5 menit
10 menit

$\checkmark$

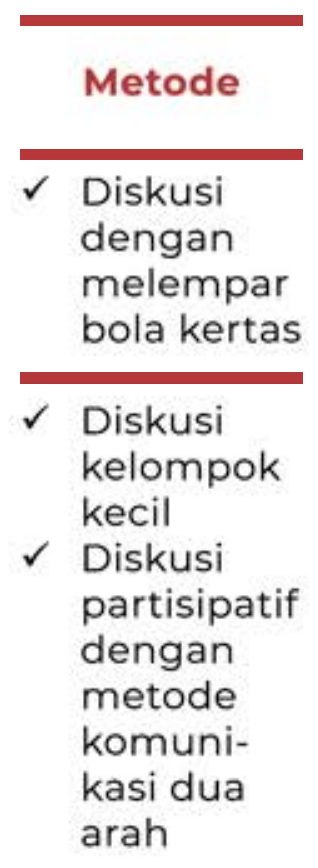

Permainan:

Bentuk tubuhku
15 menit
Media

$\checkmark$ Gambar mengenai pengertian dan faktor yang mem pengaruhi citra tubuh dan Gambar mengenai dampak dan gangguan makan karena pen garuh citra tubuh negatif dan cara menanggulanginya yang terdapat pada Modul Pendidikan dan Pemenuhan Gizi Seimbang pada Remaja Putri

$\checkmark$ Gambar bentuk tubuh

$\checkmark$ Stiker bulat warna-warni

$\checkmark$ Beberapa spidol besar

$\checkmark$ Selotip besar
Keluaran yang diharapkan

$\checkmark$ Kemampuan remaja putri mengingat dan menjelaskan kembali pesan kunci materi pada pertemuan 1

$\checkmark$ Pemahaman remaja putri mengenai konsep citra tubuh pada remaja termasuk faktor yang mempengaruhi, dampak dan penanggulangannya

$\checkmark$ Self-esteem remaja mengenai citra tubuhnya

$\checkmark$ Perilaku pencegahan dampak dari citra tubuh negatif

$\checkmark$ Pemahaman remaja putri mengenai

Standar citra tubuh mas ing-masing remaja berbe da-beda dan untuk me menuhi standar bentuk tubuh tertentu, tidak jarang remaja mengalami perilaku ganggu an makan dan konsumsi asupan gizi yang tidak seimbang 


Materi
Pembelajaran

Sesi pertemuan 3:

Diet sehat dan

gizi seimbang

pada remaja

\section{Uraian Materi dan Permainan}

Review per-

temuan 2

-

Diet sehat dan

gizi seimbang

pada remaja
Permainan: Porsi makan untuk remaja

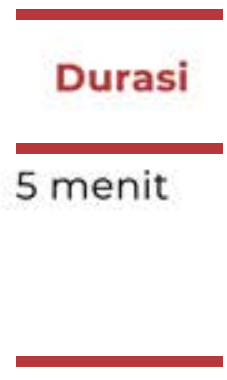

10 menit

mente

\section{$\checkmark$ Diskusi \\ dengan \\ melempar \\ bola kertas}

\section{$\checkmark$ Diskusi} kelompok kecil

$\checkmark$ Diskusi

partisipatif dengan metode komunikasi dua arah

15 menit

15 menit

Permainan peran $\checkmark$ Gambar mengenai tumpeng gizi seim bang untuk remaja putri dan Gambar pesan gizi seimbang untuk remaja putri yang terdapat pada Modul Pendidikan dan Pemenuhan Gizi Seimbang pada Remaja Putri

$\checkmark$ Foto gambar makanan
Keluaran yang diharapkan

$\checkmark$ Kemampuan remaja putri mengingat dan menjelaskan kembali pesan kunci materi pada pertemuan 2

$\checkmark$ Pemahaman remaja putri mengenai diet sehat dan pe menuhan gizi seimbang untuk remaja putri

$\checkmark$ Sikap positif remaja putri terhadap diet sehat dan pemenuhan gizi seimbang untuk remaja putri

$\checkmark$ Perilaku penerapan diet sehat dan pemenuhan gizi seim bang untuk remaja putri

$\checkmark$ Pemahaman fasilitator mengenai panduan satu porsi makan makanan yang seimbang untuk remaja putri $\checkmark$ Perilaku penerapan satu porsi makan makanan yang seimbang untuk remaja putri dalam kehidupan sehari-hari 


\section{MATERI MODUL}

\section{Sesi pertemuan 1: Permasalahan gizi pada remaja putri}

\section{Tujuan pembelajaran untuk remaja putri:}

$\checkmark$ Meningkatkan pemahaman remaja putri mengenai permasalahan anemia defisiensi zat besi dan KEK pada remaja, termasuk penyebab, gejala, dampak dan pencegahannya.

$\checkmark$ Menumbuhkan sikap positif remaja putri dalam mengonsumsi makanan kaya zat besi dan tablet tambah darah (TTD) secara patuh dan pola asupan gizi seimbang dan beragam untuk mencegah anemia dan KEK.

$\checkmark$ Mewujudkan perilaku mengonsumsi makanan kaya zat besi dan tablet tambah darah (TTD) secara patuh dan pola asupan gizi seimbang dan beragam untuk mencegah anemia dan KEK.

\section{Metode Penyampaian:}

1. Diskusi kelompok kecil

2. ATIKA sumber zat besi

Alokasi waktu: 30 menit

\section{Alat dan Media:}

Selama diskusi, fasilitator dapat menampilkan alat dan media penyampaian informasi sebagai berikut:

1. Gambar 1. Gejala anemia

2. Gambar 2. Dampak dan pencegahan anemia

3. Gambar 3. Penyebab, Dampak dan Pencegahan KEK pada remaja putri

Untuk melaksanakan permainan ATIKA sumber zat besi, fasilitator perlu menyiapkan:

1. $2,5 \mathrm{~kg}$ beras

2. 1 gelas dan 1 baskom transparan

3. Kartu Atika

4. Kartu Kerupuk

\section{Panduan proses diskusi:}

1. Fasilitator datang ke tempat diskusi sesuai janji dengan para remaja putri yang telah disepakai sebelumnya.

2. Fasilitator memberikan salam, memperkenalkan diri dan menjelaskan tujuan kegiatan

3. Fasilitator menjelaskan mekanisme diskusi yang akan berlangsung, seperti bebas untuk berpendapat dan bertanya, aktif dan fokus selama berdiskusi serta bersedia meluangkan waktu selama 30 menit untuk berdiskusi secara kondusif. 
4. Fasilitator memulai berdiskusi dengan melakukan brainstorming mengenai permasalahan gizi yang mungkin terjadi atau pernah dialami oleh remaja putri.

5. Fasilitator melanjutkan dengan menjelaskan mengenai anemia defisiensi zat besi menggunakan Gambar 1 dan 2 dan mengenai KEK menggunakan Gambar 3.

6. Fasilitator tetap terbuka untuk menanggapi apabila ada pertanyaan selama diskusi

\section{Panduan permainan ATIKA sumber zat besi:}

Tujuan permainan: untuk meningkatkan pengetahuan remaja putri bahwa beberapa makanan seperti ati ayam, telur dan ikan banyak mengandung zat besi yang dibutuhkan untuk mencegah anemia.

Langkah-langkah:

1. Teknis permainan

a. Siapkan kartu ATIKA dan beras. Ibaratkan beras sebagai nasi yang akan dibandingkan kandungan zat besinya dengan ATIKA.

Contoh:

"Adik-adik, beras ini diibaratkan nasi yang juga mengandung zat besi. Mari kita bandingkan zat besi pada ATIKA dengan nasi."

b. Mulailah permainan dengan membandingkan telur dengan nasi. Tanya kan pada peserta diskusi mengenai jumlah zat besi didalamnya.

Contoh:

"Siapa yang tahu, berapa gelas nasi yang dibutuhkan agar sebanding jumlah zat besinya dengan telur? (Minta salah satu perserta diskusi untuk yang menjawab). Ayo adik-adik, silakan untuk menuangkan beras yang kita ibaratkan nasi ini agar sebanding zat besinya dengan telur."

c. Tanyakan pada peserta lain apakah jawaban dari peserta tersebut benar dan jika ada jawaban yang lain.

Contoh:

"Apakah jawaban ini benar? Apakah ada jawaban lain? (Minta peserta diskusi yang memiliki jawaban lain untuk maju dan menambahkan/ menguragi beras pada baskom).

d. Setelah jawaban dari peserta dirasa cukup, tunjukkan jawaban yang benar dan minta satu orang untuk maju dan menuangkan beras sesuai dengan jawaban yang benar. Gunakan kartu ATIKA.

Contoh:

"Adik-adik, ternyata untuk sebanding dengan Telur, dibutuhkan 4 gelas nasi atau $51 / 2$ ons nasi. Ayo, siapa yang mau memperbaikinya. Kalo Salah? Ya Benerin!“

e. Ulangi langkah diatas untuk Ikan dan Ati Ayam. 
2. Selanjutnya coba andaikan dengan membandingkannya dengan Kerupuk. Tunjukkan Kartu Kerupuk.

Contoh:

"Sekarang coba bayangkan kalau seandainya kita bandingkan dengan keru puk. Berapa banyak kerupuk agar zat besinya sebanding dengan ATIKA? (Tunjukkan Kartu Kerupuk).“

\section{Pesan kunci:}

$\checkmark$ Harus terdapat 1 porsi ati ayam atau telur ayam atau ikan secara BERGANTIAN setiap hari pada menu makanan remaja untuk mencegah anemia.

$\checkmark$ Remaja putri harus menerapkan pola makan makanan yang bergizi seimbang dan beragam untuk mencegah terjadinya KEK pada remaja 


\section{URAIAN MATERI}

Pengaruh Gizi Remaja dalam Siklus Kehidupan 


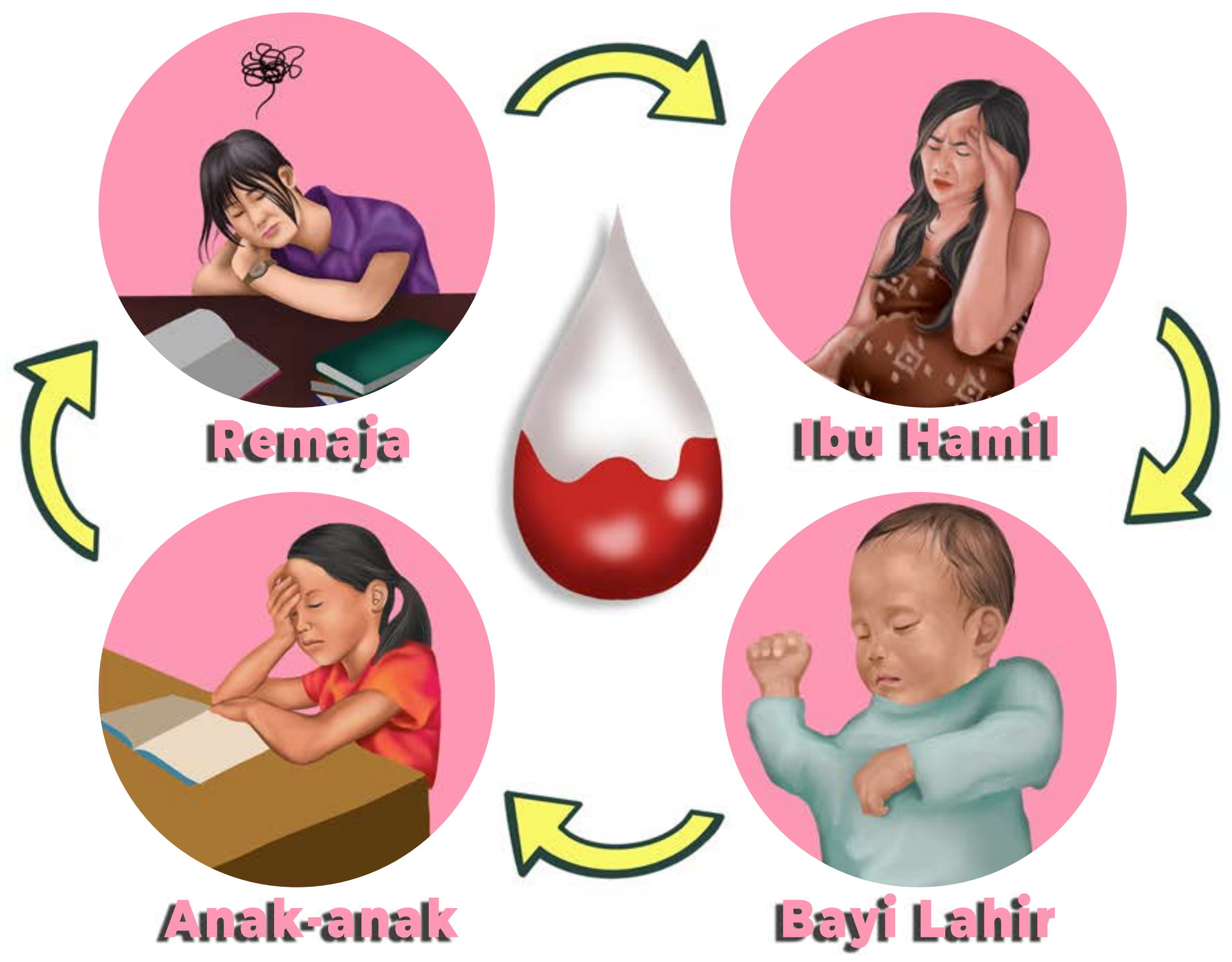

Gambar 1. Pengaruh Gizi Remaja dalam Siklus Kehidupan 


\section{Pengaruh Gizi Remaja dalam Siklus Kehidupan}

\section{Masa remaja}

$\checkmark$ Mengalami kekurangan gizi makro seperti KEK, gizi kurang dan pendek/sangat pendek

$\checkmark$ Mengalami kekurangan gizi mikro seperti anemia defisiensi besi

$\checkmark$ Mengalami kelebihan asupan makanan dan kekurangan aktivitas fisik yang menyebabkan berat badan ber lebih dan obesitas

\section{Saat remaja menjadi ibu dan hamil}

$\checkmark$ Mengalami KEK saat hamil

$\checkmark$ Mengalami anemia saat hamil

$\checkmark$ Mengalami diabetes saat hamil

\section{Saat remaja menjadi ibu dan menjalani persalinan}

$\checkmark$ Berisiko mengalami persalinan dengan penyulit, mengalami persalinan yang lama, keguguran, mengalami perdarahan pasca-bersalin serta mengalami kematian ibu

$\checkmark$ Berisiko melahirkan bayi dengan berat badan lahir rendah (BBLR), mengalami kelahiran preamatur dan ke matian janin

$\checkmark$ Berisiko mengalami keguguran, preeklamsia, tromboemboli, obstructive sleep apnea, bahkan kematian

\section{Bayi yang dilahirkan}

$\checkmark$ Bayi dengan BBLR berisiko mengalami kematian, kelainan kognitif, gangguan perilaku, gangguan tumbuh kembang, serta gangguan neurodevelopmental.

$\checkmark$ Bayi yang lahir dari ibu obesitas berisiko mengalami kelainan bawaan, seperti cacat pada saraf tulang be lakang (spina bifida) maupun penyakit jantung bawaan. Tidak hanya itu, janin juga lebih berisiko meninggal dalam kandungan.

\section{Bayi masuk masa anak-anak}

$\checkmark$ Apabila bayi dengan BBLR tidak ditanggulangi dengan pemberian asupan gizi yang adekuat, maka bayi tersebut berisiko menjadi pendek/sangat pendek saat masa anak-anak, termasuk juga mengalami gizi kurang sehingga menyebabkan produktifitas belajar dan tumbuh kembang menjadi terhambat 


\section{Masalah Gizi Remaja: Anemia Defisiensi Zat Besi}

Remaja merupakan transisi dari masa kanak-kanak ke masa dewasa yang ditandai sejumlah perubahan biologis, kognitif, dan emosional. Pertumbuhan dan perkembangan remaja yang sangat pesat membutuhkan asupan makanan bergizi seimbang, termasuk yang kaya akan zat besi. Kekurangan zat besi akan menyebabkan remaja rentan terkena anemia.
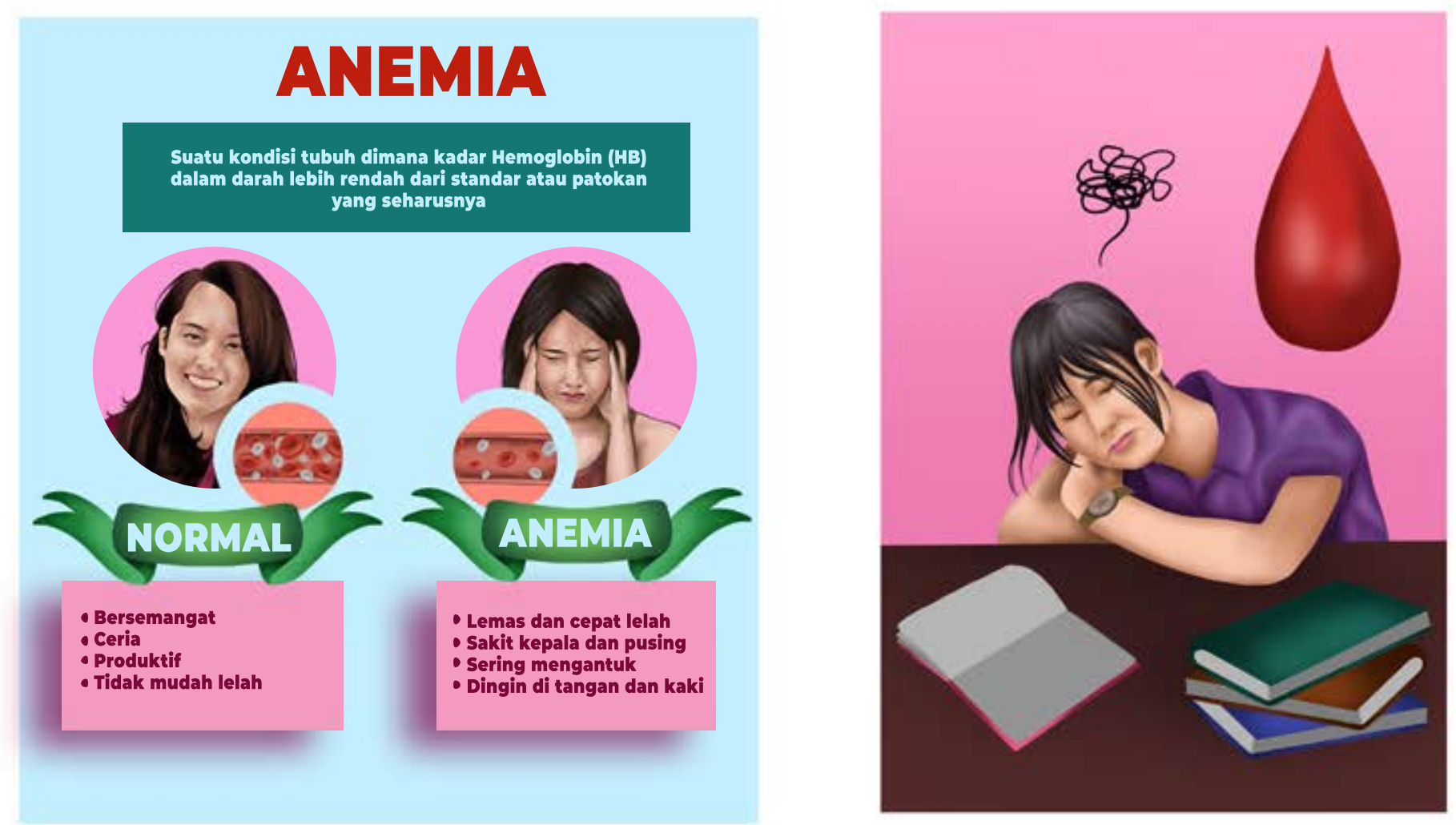

Gambar 2. Gejala Anemia

Anemia pada remaja adalah suatu keadaan kadar hemoglobin dalam darah lebih rendah dari nilai normal. Nilai batas ambang untuk anemia menurut WHO 2001 untuk remaja usia 12 tahun ke atas adalah < $12 \mathrm{~g} / \mathrm{L}$.

$\checkmark$ Anemia defisiensi zat besi disebabkan karena kandungan zat besi pada makanan yang dikonsumsi tidak mencukupi kebutuhan.

$\checkmark$ Gejala anemia pada remaja adalah sering mengalami $5 \mathrm{~L}$ (lesu, lemah, letih, lelah dan lalai) sehingga berdampak pada konsentasi dan produktifitas. 


\section{Masalah Gizi Remaja: Anemia Defisiensi Zat Besi}

\section{Dampak jangka pendek anemia:}

$\checkmark$ Konsentrasi menurun

$\checkmark$ Daya tahun tubuh melemah

$\checkmark$ Tidak bugar dan kurang produktif

\section{Dampak jangka panjang anemia:}

$\checkmark$ Berisiko anemia saat menjadi ibu hamil

$\checkmark$ Melahirkan bayi dengan berat badan rendah

$\checkmark$ Bayi lahir prematur

$\checkmark$ Meningkatkan risiko kematian ibu saat melahirkan

\section{Cara mencegah anemia:}

$\checkmark$ Konsumsi makanan kaya zat besi seperti daging, ati ayam, ikan dan telur secara bergantian

$\checkmark$ Menghindari konsumsi teh, kopi, susu dan minuman bersoda saat makan, karena dapat menghambat penyerapan zat besi dari makanan ke dalam tubuh

$\checkmark$ Mengonsumsi makanan yang mengandung vitamin A dan C, seperti buah jeruk yang padat meningkatkan penyerapan zat besi

$\checkmark$ Minum tablet tambah darah (TTD) yang diperoleh di sekolah 1 kali seminggu secara patuh dan rutin. Apabila tidak ada kegiatan belajar di sekolah, dapat berkoordinasi dengan guru atau pembina UKS untuk mendapatkan TTD setiap minggunya.

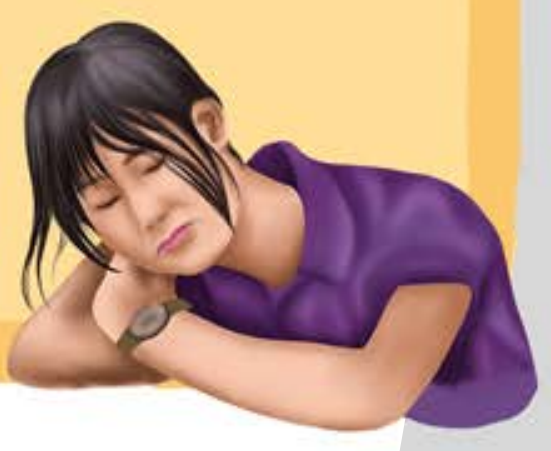




\section{Masalah Gizi Remaja: Kekurangan Energi Kronis}

Kurang gizi pada remaja putri yang disebut kurang energi kronik (KEK) ditandai dengan lingkar lengan atas (LiLA) kurang dari $23,5 \mathrm{~cm}$. Pada umumnya, hal tersebut disebabkan karena remaja putri makan terlalu sedikit karena keinginan untuk menurunkan berat badan.

\section{Kurang Energi Kronis (KEK)}

\section{Penyebab:}

$\checkmark$ Pemenuhan asupan energi tidak mencukupi kebutuhan tubuh dalam waktu lama

\section{Tanda-tanda:}

$\checkmark$ Hasil pengukuran Lingkar Lengan Atas (LiLA) yang kurang dari $23,5 \mathrm{~cm}$

$\checkmark$ Tanda-tanda awal: terus-menerus merasa letih dan sering mengalami kesemutan

\section{Dampak jangka pendek:}

$\checkmark$ Adanya gangguan pada kenaikan berat badan yang tidak sesuai dengan standar

$\checkmark$ Cepat merasa lelah

$\checkmark$ Mudah terkena infeksi penyakit

\section{Dampak jangka panjang saat hamil dan melahirkan:}

$\checkmark$ Berisiko mengalami persalinan dengan penyulit

$\checkmark$ Berisiko mengalami persalinan yang lama

$\checkmark$ Berisiko mengalami keguguran

$\checkmark$ Berisiko mengalami perdarahan pasca-bersalin

$\checkmark$ Berisiko mengalami kematian ibu

\section{Pencegahan:}

$\checkmark$ Menerapkan pola asupan gizi seimbang dan beragam selama masa remaja

$\checkmark$ Apabila mengalami KEK maka perlu meningkatkan porsi makanan yaitu satu porsi lebih banyak daripada biasanya. 


\section{Daftar Pertanyaan dan Jawaban}

\section{Pertanyaan}

Apakah menstruasi menyebabkan remaja putri menjadi anemia?

Bagaimana caranya agar menstruasi tidak sakit atau nyeri sehingga tidak mengganggu aktivitas?

\section{Jawaban}

Banyak studi yang menghubungkan antara kejadian anemia dan menstruasi. Keluarnya darah dari tubuh remaja putri saat menstruasi mengakibatkan hemoglobin yang terkandung dalam sel darah merah juga ikut terbuang, sehingga cadangan zat besi dalam tubuh berkurang. Berkurangnya cadangan zat besi dalam tubuh ini dapat mengakibatkan anemia. Berdasarkan hal itu, remaja putri harus secara RUTIN mengonsumsi makanan kaya zat besi dan minum tablet tambah darah.

Terdapat beberapa hal yang menyebabkan nyeri saat menstruasi seperti adanya kontraksi otot pada rahim ataupaun kondisi penyakit tertentu seperti radang panggul dan lainnya, yang mana harus dieperiksakan ke dokter apabila nyeri tidak tertahankan. Terdapat beberapa tips cara mengatasi nyeri saat menstruasi, yaitu:

1. Memberikan kompres hangat di perut bagian bawah yang terasa nyeri atau kram

2. Memperbanyak aktivitas fisik atau olahraga

3. Melakukan teknik relaksasi, seperti meditasi, yoga, dan latihan pernapasan

4. Membatasi konsumsi makanan berlemak dan minuman yang mengandung kafein serta alkohol

5. Mencukupi kebutuhan cairan dengan minum air putih

6. Mengonsumsi teh herbal, seperti teh chamomile dan jahe

7. Mengurangi stres

8. Menggunakan obat pereda nyeri yang dijual bebas, seperti paracetamol 


\section{MATERI MODUL}

\section{Sesi pertemuan 2: Citra tubuh yang Sehat dan Tepat}

\section{Tujuan pembelajaran untuk remaja putri:}

$\checkmark$ Meningkatkan pemahaman remaja putri mengenai konsep citra tubuh pada remaja termasuk faktor yang mempengaruhi, dampak dan penanggulangan nya

$\checkmark$ Menumbuhkan self-esteem remaja mengenai citra tubuhnya

$\checkmark$ Mewujudkan perilaku pencegahan dampak dari citra tubuh yang negatif

\section{Metode Penyampaian:}

1. Permainan bentuk tubuhku

2. Diskusi kelompok kecil

Alokasi waktu: 30 menit

\section{Alat dan Media:}

Selama diskusi, fasilitator dapat menampilkan alat dan media penyampaian informasi sebagai berikut:

1. Gambar 4. Pengertian dan faktor yang mempengaruhi citra tubuh

2. Gambar 5. Dampak dan gangguan makan karena pengaruh citra tubuh negatif

3. Gambar 6. Tips cara menanggulangi citra tubuh negatif

Untuk melaksanakan permainan bentuk tubuhku, fasilitator perlu menyiapkan:

1. 2 set gambar terdiri dari 10 bentuk tubuh perempuan

2. Stiker bulat warna-warni

3. Beberapa spidol besar

4. Selotip besar

\section{Panduan review materi pertemuan 1:}

1. Fasilitator datang ke tempat diskusi sesuai janji dengan para remaja putri yang telah disepakai sebelumnya.

2. Fasilitator menjelaskan mekanisme diskusi yang akan berlangsung, seperti bebas untuk berpendapat dan bertanya, aktif dan fokus selama berdiskusi serta bersedia meluangkan waktu selama 30 menit untuk berdiskusi secara kondusif.

3. Fasilitator mulai review dengan melemparkan bola yang terbuat dari gulu ngan kertas bekas secara sembarang ke arah peserta. Kemudian peserta yang terkena atau menangkap bola akan diminta untuk menyebutkan atau menjelaskan materi yang telah diperoleh dari pertemuan pertama. 
4. Setelah selesai memberikan review, peserta tersebut melemparkan bola dengan sembarang ke peserta lainnya. Peserta yang terkena atau menangkap bola akan diminta untuk memberikan penjelasanan tambahan menge nai penjelasan peserta sebelumnya. Lanjutkan dengan melakukan beberapa kali lemparan bola.

\section{Panduan permainan bentuk tubuhku:}

Tujuan permainan: meningkatkan pemahaman remaja putri mengenai standar citra tubuh masing-masing remaja berbeda-beda dan untuk memenuhi standar bentuk tubuh tertentu, tidak jarang remaja mengalami perilaku gangguan makan dan konsumsi asupan gizi yang tidak seimbang

Langkah-langkah:

1. Fasilitator memulai permainan dengam memperlihatkan gambar bentukbentuk tubuh

2. Fasilitator membagikan stiker warna hijau kepada peserta dan mempersilahkan mereka menempel stiker pada gambar bentuk tubuh (set 1) yang menurut mereka paling ideal.

3. Setelah semua peserta menempel stiker, fasilitator mengajak peserta berdiskusi.

Contoh:

"Adik-adik mengapa sebagian besar menempel stiker pada bentuk tubuh itu? siapa yang mempengaruhinya? apakah ini murni pilihan pribadi atau ikut teman?"

4. Kemudian fasilitator kembali membagikan stiker berwarna merah kepada peserta. Kali ini peserta diminta untuk menempelkan stiker pada gambar bentuk-bentuk tubuh (set 2) yang menurut mereka paling sesuai dengan keadaan bentuk tubuh mereka saat ini.

5. Setelah semua peserta menempel stiker, fasilitator membandingkan dua set gambar bentuk tubuh dan mengajak peserta berdiskusi.

Contoh:

"Apakah adik-adik melihat perbedaan antara kedua penempelan stiker pada gambar bentuk tubuh? Mengapa demikian?". Pilih beberapa peserta untuk menyimpulkan arti dari kedua set gambar tersebut.

6. Pada akhir permainan fasilitator menekankan mengenai adanya citra tubuh yang bebeda-beda di setiap orang, terkadang citra tubuh yang diharapkan tidak sesuai dengan kenyataan.

\section{Panduan proses diskusi:}

1. Selesai melaksanakan permainan, fasilitator menggiring sesi diskusi dengan menjelaskan mengenai citra tubuh menggunakan Gambar 4-6.

2. Fasilitator tetap terbuka untuk menanggapi apabila ada pertanyaan selama diskusi.

Pesan kunci: hindari diet yang tidak sehat dan gangguan makan untuk mencapai citra tubuh yang diinginkan 


\section{URAIAN MATERI}

Konsep Citra tubuh 


\section{Konsep Citra tubuh}

Citra tubuh adalah gambaran persepsi seseorang tentang tubuh ideal dan apa yang mereka inginkan terhadap tubuh mereka.

$\checkmark$ Persepsi Citra tubuh bisa terkait dengan berat badan maupun bentuk tubuh yang didasarkan pada persepsi orang lain dan seberapa mereka menyesuaikan dengan persepsi tersebut.

$\checkmark$ Apabila seseorang menganggap kondisi fisiknya tidak sama dengan konsep ideal maka individu akan merasa mempunyai kekurangan fisik.

$\checkmark$ Keadaan tersebut menyebabkan seseorang tidak dapat menerima kondisi fisiknya secara apa adanya sehingga citra tubuhnya negatif.

\section{Faktor yang mempengaruhi citra tubuh}

Adapun faktor-faktor yang mempengaruhi perkembangan citra tubuh adalah sebagai berikut:

Jenis kelamin
terjadi pada kaum perempuan. Perempuan lebih kritis ter-
hadap tubuhnya dan mempunyai citra tubuh yang negatif.
kersepsi citra tubuh yang negatif pada perempuan ber-
kaitan dengan perasaan kelebihan berat badan.

\section{Budaya}

Pengaruh budaya dalam perkembangan citra tubuh berkaitan dengan lingkungan disekitar individu dan cara budaya mengkomunikasikan norma-norma tentang i penampilan fisik, dan ukuran tubuh yang menarik.

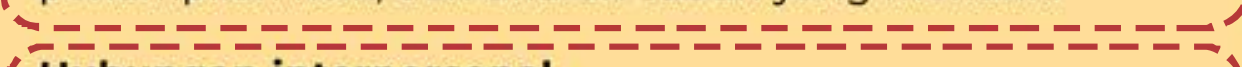

Hubungan interpersonal membuat seseorang cenderung

membandingkan diri dengan orang lain dan feedback

yang diterima mempengaruhi konsep diri termasuk mem-

pengaruhi bagaimana perasaan terhadap penampilan

I fisik. Hal inilah yang sering membuat orang merasa

I cemas dengan penampilannya dan gugup ketika orang

I lain melakukan evaluasi terhadap dirinya.

I sópialisasi

Sosialisasi

I Konsep pembentukan citra tubuh bergantung dengan

I proses sosialisasi seperti adanya pengaruh dari teman

I sebaya yang menjadikan individu ikut terpengaruh dida-

I lamnya. 


\section{I'Dampak positif:}

Citra tubuh dapat berdampak positif jika mendorong seseorang senantiasa merawat dirinya dan memperbaiki pola hidupnya agar dapat tampil secara prima.

\section{Dampak negatif:}

Diet yang tidak sehat

$\checkmark$ Merupakan perilaku mengonsumsi makanan dengan asupan gizi yang tidak seimbang, biasanya tinggi lemak dan rendah

I protein, ataupun tinggi asupan gula dan garam.

I Biasanya menghindari makanan utama dan menggantikannya dengan camilan atau snack yang tidak sehat.

I Melakukan aktivitas fisik atau olah raga yang berlebihan dan tidak diimbangi atau tidak sesuai dengan asupan makanan.

iv Menargetkan penurunan berat badan yang ekstrem sehingga tidak sesuai dengan indeks masa tubuh (IMT) yang normal.

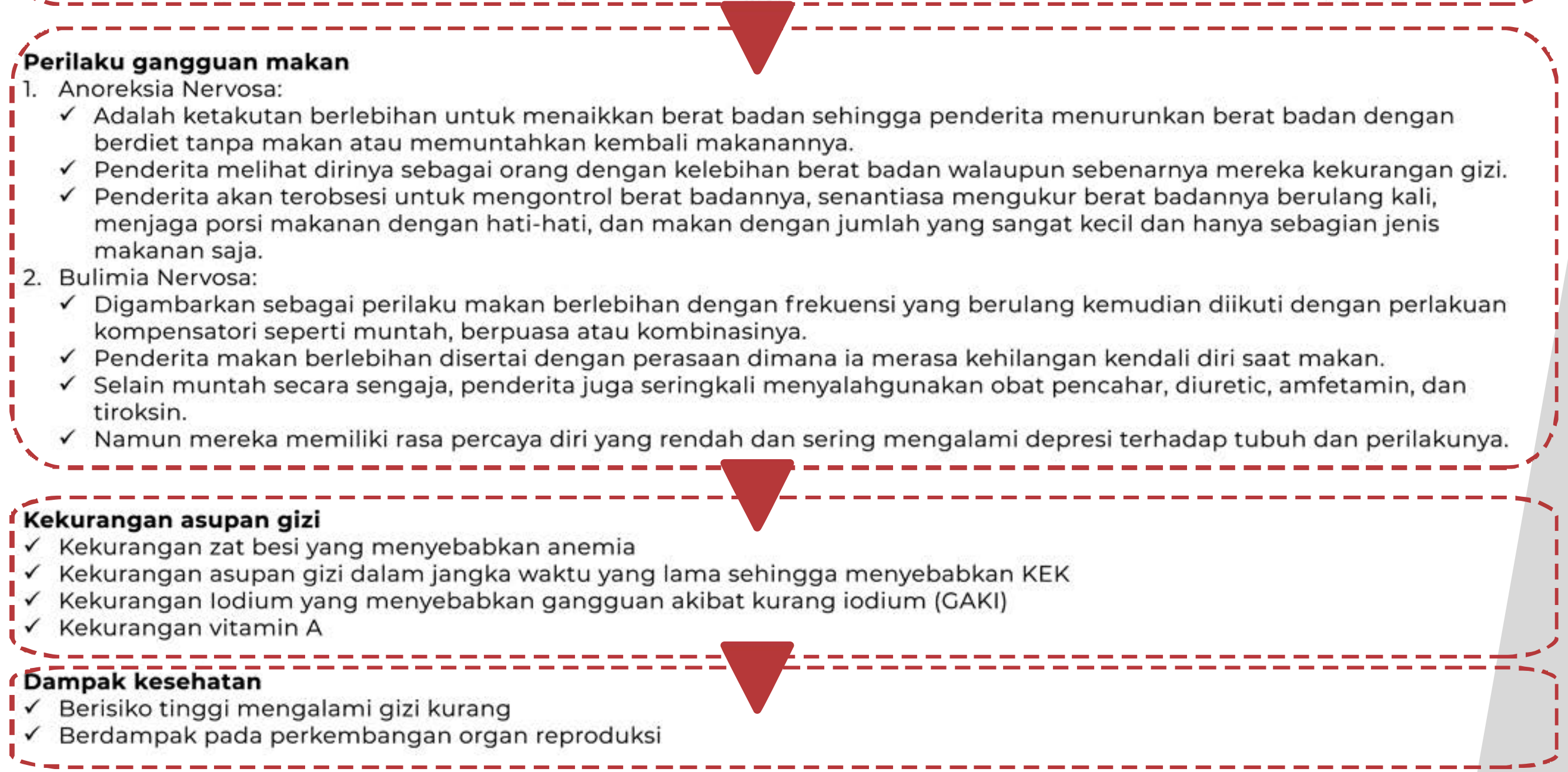

Gambar 6. Dampak dan gangguan makan karena pengaruh citra tubuh negatif 
1. Perbaiki kepercayaan diri. Rasa percaya diri akan muncul jika remaja memiliki pandangan yang baik terhadap dirinya sendiri. Selalu berpikir cantik berkaitan dengan hati dan pikiran.

2. Tumbuhkan sikap positif. Sikap ini akan muncul jika kita sudah menerima seluruh kelebihan dan kekurangan diri sendiri.

3. Kuatkan emosi saat menghadapi orang lain. Remaja harus mampu menjaga perasaan dalam menghadapi perkataan negative orang lain. Kelilingi diri dengan orang-orang positif dan mendukung diri kita.

4. Mulai melakukan diet yang tepat dan sehat. Remaja dapat mulai merencanakan bentuk atau berat badan sesuai yang diharapkan dengan melakukan diet sehat dengan supan gizi yang seimbang serta dibarengi dengan aktifitas fisik yang selaras. Mulailah konsultasikan rencana diet dengan orang tua, guru atau ahli gizi.

5. Membentuk citra tubuh positif sebagai dasar "merawat diri". Hal yang dapat dilakukan untuk merawat diri untuk menumbuhkan citra tubuh positif adalah:

$\checkmark$ Mengatur pola makan dengan melakukan diet yang sehat dan tepat melalui pola makan makanan dengan asupan gizi seimbang dan beragam.

$\checkmark$ Melakukan aktivitas fisik atau olah raga secara rutin dan tidak berlebihan

$\checkmark$ Menjaga kebersihan diri dan kebersihan di lingkungan sekitar

$\checkmark$ Istirahat dan tidur yang cukup.

$\checkmark$ Merawat dan memperhatikan kesehatan mental dengan cara menerima kekurangan dan kelebihan diri sendiri tanpa harus membandingkan dengan kondisi dan bentuk tubuh orang lain

$\checkmark$ Menciptakan energi yang positif di lingkungan pertemanan, misalkan dengan tidak melakukan pelabelan atau perundungan berdasarkan bentuh tubuh teman sebaya, melainkan saling dukung untuk merawat diri dan membentuk citra tubuh positif.

Gambar 7. Tips cara menanggulangi citra tubuh negatif 
Studi kasus: Citra tubuh dan pengukuran indeks masa tubuh

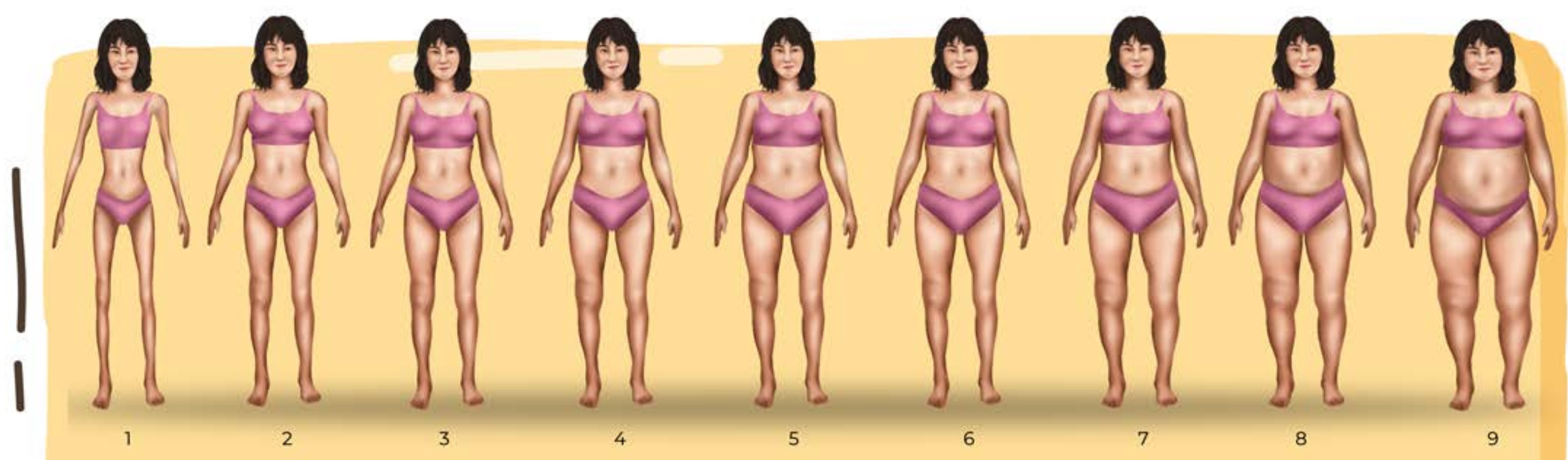

Pengantar:

Hasil penelitian pada remaja putri di Desa Ban menunjukkan bahwa sebagian besar remaja memilih bentuk tubuh dengan berat badan kurang yaitu 1 (15\%), 2 (37.5\%), 3 (27.5\%) sebagai bentuk tubuh yang mencerminkan tubuh mereka saat ini. Dimana bentuk tubuh ideal bagi mereka ada pada kisaran gambar 2 (30\%) sampai $3(47.5 \%)$ yang merupakan bentuk tubuh dengan berat badan kurang. Bentuk tubuh yang paling menarik menurut remaja ada pada bentuk tubuh nomor 2 sampai 4, dan 52.5\% memilih bentuk tubuh nomor 4 sebagai bentuk tubuh yang sehat, sedangkan bentuk tubuh nomor 9 sebagai bentuk tubuh yang tidak sehat (50\%). Jika dilihat dari pertanyaan terkait bentuk tubuh yang diharapkan oleh lingkungan mereka, remaja memilih bentuk tubuh nomor 3 (30\%) yang diharapkan keluarga, (40\%).

Jadi bagaimana kita tahu mengenai kondisi atau komposisi badan kita? apakah kita termasuk gemuk, kurus atau tubuh ideal? Salah satu caranya adalah dengan menghitung indeks masa tubuh. 


\section{Studi kasus: Citra tubuh dan pengukuran indeks masa tubuh}

\section{Tujuan mengukur indeks masa tubuh:}

$\checkmark$ Untuk mengetahui komposisi berat badan dan tinggi badan kita

$\checkmark$ Untuk menghindari pengaruh citra tubuh yang negatif dan berdampak pada gangguan perilaku makan dan asupan gizi

$\checkmark$ Untuk membantu merencanakan asupan makanan dan aktifitas fisik untuk mecapai indeks masa tubuh yang normal atau ideal

\section{Cara mengukur indeks masa tubuh:}

Dengan membagi berat badan dalam kilogram dengan tinggi badan dalam meter kuadrat.

Misalnya Anda memiliki berat badan 60 kilogram dan tinggi 1,60 m (160 centimeter).

Pertama, kalikan tinggi badan dalam kuadrat: 1,60 $1,60=$ 2,56 .

Selanjutnya, bagi angka berat badan dengan hasil kuadrat tinggi badan: $60 / 2,56=23,4$.

Terakhir, bandingkan angka BMI Anda $(23,4)$ dengan kategori usia yang tercantum dalam tabel di Lampiran 2 apakah Anda termasuk dalam kategori indeks masa tubuh yang ideal?

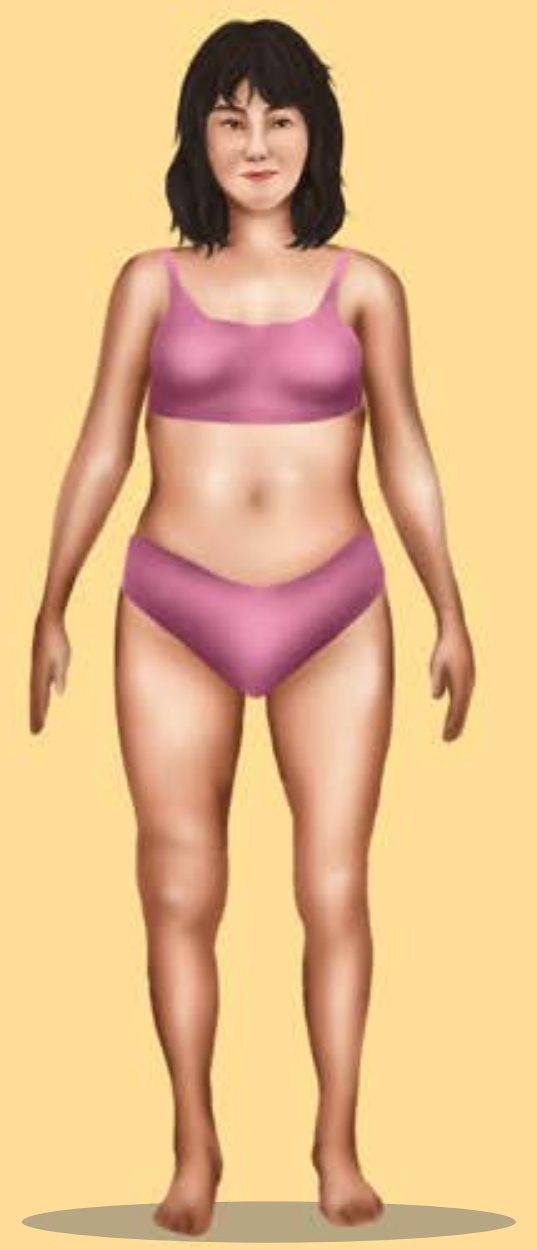




\section{MATERI MODUL}

\section{Sesi pertemuan 3: Diet Sehat dan Gizi Seimbang pada Remaja}

\section{Tujuan pembelajaran untuk remaja putri:}

$\checkmark$ Meningkatkan pemahaman remaja putri mengenai konsep diet sehat dan gizi seimbang selama masa remaja

$\checkmark$ Menumbuhkan sikap positif remaja terhadap konsep diet sehat dan gizi seimbang selama masa remaja

$\checkmark$ Mewujudkan perilaku diet sehat dan pemenuhan gizi seimbang selama masa remaja

\section{Metode Penyampaian:}

1. Diskusi kelompok kecil

2. Permainan porsi makan untuk remaja

Alokasi waktu: 30 menit

\section{Alat dan Media:}

Selama diskusi, fasilitator dapat menampilkan alat dan media penyampaian informasi sebagai berikut:

1. Gambar 7. Tumpeng gizi seimbang untuk remaja putri

2. Gambar 8 . Pesan gizi seimbang untuk remaja putri

Untuk melaksanakan permainan porsi makan untuk remaja, fasilitator perlu menyiapkan:

1. Gambar foto makanan sumber zat tenaga (karbohidrat), seperti: beras/nasi, umbi-umbian dan jagung.

2. Gambar foto makanan sumber zat pembangun (protein hewani dan nabati), seperti: daging, ikan, ayam, ati ayam, telur, tahu, tempe dan kacangkacangan.

3. Gambar foto makanan sumber zat pengatur (vitamin dan mineral), seperti: sayuran dan buah-buahan.

4. Gambar foto makanan yang berisikan 1 piring/porsi makanan untuk 1 kali makan bagi remaja putri.

\section{Panduan review materi pertemuan 2:}

1. Fasilitator datang ke tempat diskusi sesuai janji dengan para remaja putri yang telah disepakai sebelumnya.

2. Fasilitator menjelaskan mekanisme diskusi yang akan berlangsung, seperti bebas untuk berpendapat dan bertanya, aktif dan fokus selama berdiskusi serta bersedia meluangkan waktu selama 30 menit untuk berdiskusi secara kondusif. 
3. Fasilitator mulai review dengan melemparkan bola yang terbuat dari gulungan kertas bekas secara sembarang ke arah peserta. Kemudian peserta yang terkena atau menangkap bola akan diminta untuk menyebutkan atau menjelaskan materi yang telah diperoleh dari pertemuan kedua.

4. Setelah selesai memberikan review, peserta tersebut melemparkan bola dengan sembarang ke peserta lainnya. Peserta yang terkena atau menang kap bola akan diminta untuk memberikan penjelasanan tambahan menge nai penjelasan peserta sebelumnya. Lanjutkan dengan melakukan beberapa kali lemparan bola.

\section{Panduan proses diskusi:}

1. Fasilitator memulai diskusi dengan melakukan brainstorming mengenai pola makan dan jenis makanan yang biasa dikonsumsi oleh remaja baik di rumah maupun di luar rumah bersama teman sebayanya.

Contoh:

"Adik-adik ada yang bisa cerita biasanya jenis makanan apa yang dikonsumsi? Apa lagi? Apakah pilihan jenis makanan berbeda saat di dalam rumah dan di luar rumah dengan teman-teman? siapa yang menentukan konsumsi jenis makanan tersebut?

2. Fasilitator melanjutkan menjelaskan mengenai diet dan pola asupan gizi seimbang untuk remaja menggunakan Gambar 7 dan 8.

3. Fasilitator tetap terbuka untuk menanggapi apabila ada pertanyaan selama diskusi.

\section{Panduan permainan porsi makan remaja:}

Tujuan permainan: untuk meningkatkan pengetahuan remaja putri mengenai pentingnya memenuhi kebutuhan asupan gizi seimbang selama masa remaja.

Langkah-langkah:

1. Berikan pertanyaan terbuka mengenai makanan ada saja yang ada disekitar dan terjangkau untuk dikonsumsi oleh remaja.

Contoh:

"Ada yang bisa mengulang dari paparam materi tadi, makanan apa saja yang wajib dikonsumsi oleh remaja putri?" "Ada yang bisa menyebutkannya?"

2. Kemudian tunjukkan beberapa gambar foto makanan. Peserta diskusi untuk mendiskusikan foto makanan mana yang merupakan makanan pokok/sumber tenaga, makanan sumber zat pembangun dan pengatur.

3. Kemudian diskusikan mengenai kemungkinan keluarga remaja atau remaja sendiri untuk mendapatkan/membeli makanan-makanan tersebut untuk dikonsumsi. Tanyakan mengapa bisa atau tidak bisa mendapatkannya. Apabila tidak bisa mendapatkannya, diskusikan bersama makanan alternatif yang lebih mudah diperoleh dan terjangkau.

4. Berikan pertanyaan pancingan mengenai porsi makan remaja putri dalam 1 kali makan.

Contoh:

"Adik-adik ada yang tahu sebapa banyak/porsi makan makanan pokok untuk remaja putri?" "Bagaimana dengan porsi protein nabati dan hewani serta sayuran dan buahnya?" 
5. Tunjukkan foto gambar piring yang berisikan 1 porsi makanan untuk remaja putri dalam 1 kali makan. Tanyakan bagaimana pendapat mereka. Diskusinya kemungkinan pemenuhan porsi makanan tersebut setiap harinya.

6. Pancing peserta dengan menanyakan upaya lainnya untuk memenuhi asupan gizi dan diet yang sehat untuk remaja.

Contoh:

"Adik-adik tadi kita sudah diskusi mengenai jenis dan porsi makan yang seimbang untuk remaja, ada yang bisa menyebutkan kembali, selain pengaturan makan, upaya apa saja yang perlu dilakukan untuk mewujudkan pola diet yang sehat?

7. Fasilitator menutup diskusi dengan mengajak remaja menyusun rencana tindak lanjut mengenai hasil diskusi selama 3 kali pertemuan.

Contoh:

"Adik-adik mari kita menyusun rencana apa yang akan kalian lakukan setelah ikut dalam 3 kali pertemuan diskusi ini" "Akankan kalian menyebarkan informasi yang kalian peroleh dalam diskusi ke keluarga?" "Bagaimana dengan menyebarkannya ke teman sebaya?" "Bagaimana caranya?"

Pesan kunci: Remaja putri harus mengonsumsi makanan yang beragam dengan asupan gizi yang seimbang, serta diimbangi dengan aktifitas fisik, pemantauan berat badan dan perilaku menjaga kebersihan diri. 


\section{URAIAN MATERI}

Diet Sehat dan Seimbang pada Remaja 


\section{Diet Sehat dan Seimbang pada Remaja}

$\checkmark$ Diet sehat adalah pengaturan pola makan dengan mengonsumsi makanan tertentu yang sumbernya dan cara memasaknya diatur sedemikian rupa untuk mencapai atau menjaga berat badan sehingga menjadi terkontrol, tidak hanya terlihat ideal secara fisik, namun juga tetap sehat dan terpenuhi segala zat gizi yang diperlukan remaja sesuai usia dan jenis kelamin.

$\checkmark$ Pertumbuhan linier (tinggi badan) yang pesat terjadi pada awal remaja. Hal ini berdampak pada pentingnya pemenuhan asupan energi, protein, lemak, air, kalsium, magnesium, vitamin D dan vitamin A.

$\checkmark$ Selain melaksanakan kegiatan untuk pengaturan makanan, terdapat beberapa aktivitas lainnya yang juga perlu dijalankan secara berkesinambungan yaitu diantaranya:

- Aktivitas fisik yang sesuai dengan asupan makanan

- Mencuci tangan dengan sabun pada air mengalir sebelum makan/minum atau setelah buang air besar (BAB)

- Memantau berat badan, yang bertujuan untuk perencanaan mengurangi atau menambah asupan makanan atau aktivitas fisik agar berat badan tetap ideal

- Minum air putih, termasuk saat makan dan tidak minum minuman lainnya, seperti soda, minuman perasa dan lainnya 


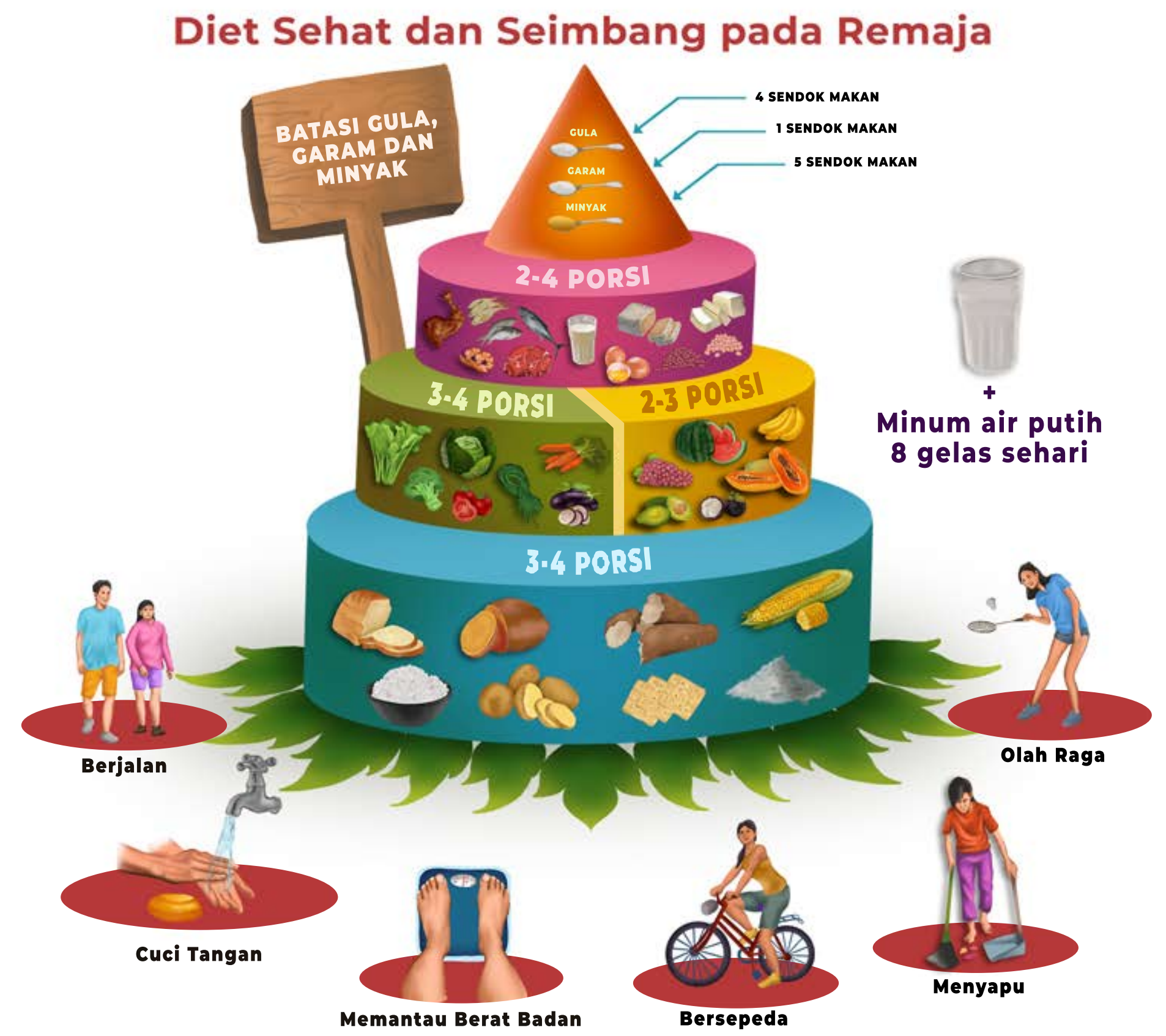

Gambar 8. Tumpeng gizi seimbang untuk remaja 


\section{Diet Sehat dan Seimbang pada Remaja}

\section{Pesan Gizi Seimbang}

Biasakan mengonsumsi beraneka ragam makanan

Banyak makan sayuran hijau dan buah berwarna

Biasakan makan $3 x$ sehari

Biasakan mengonsumsi ikan, daging dan protein lainnya

Biasakan membawa bekal makanan dan air putih dari rumah

Batasi konsumsi makanan cepat saji, jajanan dan makanan selingan yang manis, asin, dan berlemak

Hindari merokok dan minum alkohol

Gambar 9. Pesan gizi seimbang untuk remaja putri 


\section{Studi Kasus: Pengaruh Media dalam Pemilihan Makan pada Remaja}

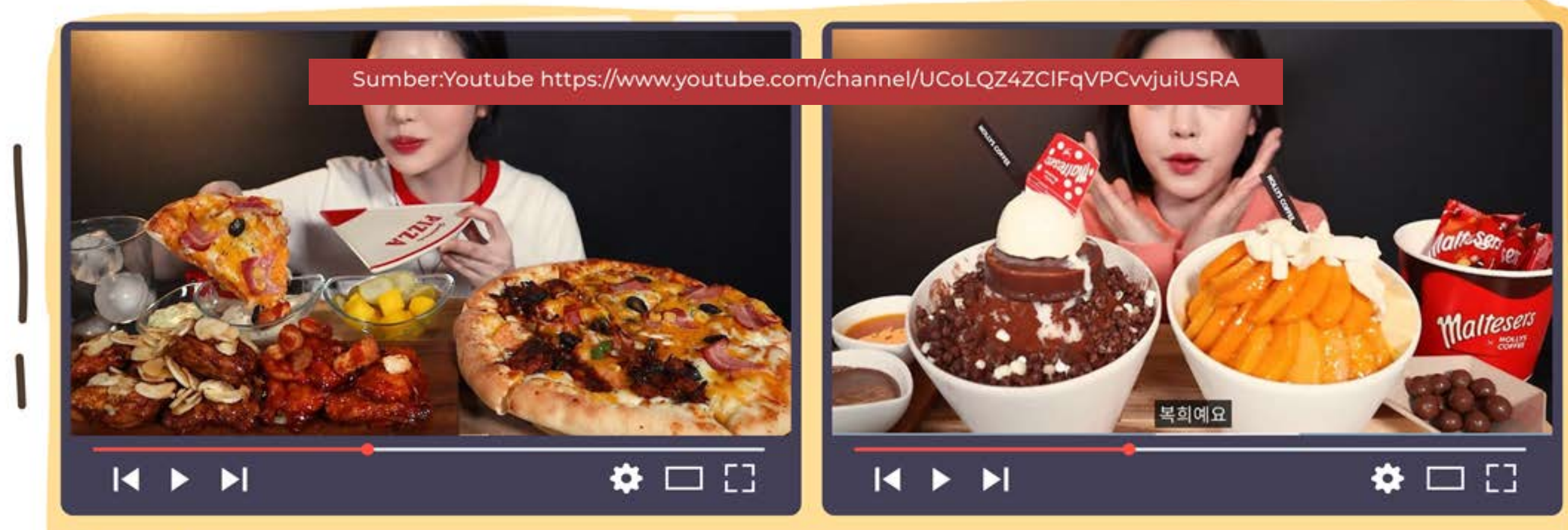

\section{Pengantar:}

Pada masa kini remaja seperti tidak bisa dipisahkan dari gawai dan internet. Salah satu konten atau topik yang paling populer di kalangan remaja adalah konten tentang makanan. Di sosial media seperti Instagram, Facebook, Twitter dan lainnya banyak bermunculan akun khusus tempat makan atau influencer yang berfokus pada eksplorasi makanan. Selain itu pada platform digital seperti Youtube banyak bermunculan influencer yang memiliki konten video makan atau yang sering disebut dengan "Mukbang". Biasanya mukbang dilakukan dengan menyediakan makanan yang enak, namun tinggi kalori, tinggi lemak, gula dan garam serta dalam jumlah yang sangat banyak dan dimakan dalam waktu yang cukup singkat. Selain itu, tidak sedikit dari pelaku mukbang di Youtube terlihat secara fisik memiliki tubuh yang ideal, dalam arti tidak terlihat terlalu gemuk walaupun dalam video yang diunggahnya di Youtube, mereka terlihat melakukan mukbang dalam porsi yang sangat banyak dan dilakukan hampir setiap hari. Namun, tidak banyak dari mereka yang mengungkapkan bagaimana pola aktifitas fisik atau olahraga yang mereka lakukan untuk mengimbangi asupan makanan berlebih yang mereka terima. 


\section{Studi Kasus: Pengaruh Media dalam Pemilihan Makan pada Remaja}

\section{Diskusi:}

Fasilitator dapat memulai diskusi dengan bertanya:

"Apakah adik-adik punya pengalaman menyaksikan mukbang atau konten-konten tentang makanan lainnya? Dapatkan adik-adik menceritakanya?"

"Bagaimana perasaan adik-adik setelah menyaksikan konten-konten tentang makanan tersebut? Apakah ada peningkatan nafsu makan?

"Menurut adik-adik apakah makanan yang ditampilkan dalam konten tersebut sehat atau dikonsumsi dengan gizi yang seimbang? Kenapa?

"Menurut adik-adik bagaimana cara para pelaku mukbang mendapatkan bentuk tubuh yang tetap ideal arau tidak menjadi gemuk? Apakah ada kemungkinan terjadi perilaku gangguan makan?

"Menurut adik-adik apakah konten-konten tentang makanan tersebut membawa dampak pada pola makan remaja? Seperti apa?

\section{Penutup:}

Berdasarkan penelitian yang dilakukan oleh Ardini dkk, memang konten tentang makanan seperti mukbang dapat membawa dampak positif dan negatif pada kesehatn remaja. Salah satu dampak negatifnya adalah pola pemilihan makanan pada remaja yang cenderung memilih makanan yang tidak sehat (tinggi kalori, lemak, gula dan garam serta dalam porsi yang sangat banyak dan tidak sesuai dengan kebutuhan tubuh dan pola aktivitas fisik). 


\section{REFERENSI}

Almatsier, S (2010) Prinsip Dasar IImu Utama. Jakarta: PT Gramedia Pustaka.

Ardrini, DAM, et al (2020) 'I want what they're eating': Collage Student Experiences of

Watching Food Content on YouTube. Denpasar: Fakultas Kedokteran

Universitas Udayana

Denich, A. U., \& Ifdil (2015). Konsep Body Image remaja Putri. Jurnal Konseling dan Pendidikan, III (2), 55-61.

Kemendikbud RI (2019). Buku Pedoman dan Kumpulan Rencana Ajar untuk Guru Sekolah Menengah dan yang Sederajat: Gizi dan Kesehatan Remaja. Jakarta:

Southeast Asian Ministers of Education Organization Regional Centre for Food and Nutrition (SEAMEO RECFON), Kementerian Pendidikan dan Kebudayaan Republik Indonesia.

Kemenkes (2019). Buku Panduan Siswa AKSI BERGIZI. Jakarta: Kementerian

Kesehatan Republik Indonesia.

Kemenkes (2018). Modul Kesehatan dan Gizi. Jakarta: Kementerian Kesehatan Republik Indonesia.

Kemenkes (2019a) Laporan Nasional Riskesdas 2018. Jakarta.

Kemenkes (2019b) Laporan Provinsi Bali Riskesdas 2018. Jakarta.

Kemenkes (2020) Indikator Program Kesehatan Masyarakat dalam RPJMN dan Renstra Kementerian Kesehatan 2020-2024. Jakarta.

Lubis, D. et al. (2020) Potret Permasalahan Gizi di Desa Ban, Kecamatan Kubu, Kabupaten Karangasem, Bali, 2020. Denpasar.

Utter, J. et al. (2019) "Feasibility of a Family Meal Intervention to Address Nutrition, Emotional Wellbeing, and Food Insecurity of Families With Adolescents.," Journal of nutrition education and behavior. United States, 51(7), pp. 885-892. doi: 10.1016/j.jneb.2019.03.015. 


\section{Protokol Kesehatan selama implementasi intervensi pendidikan kesehatan dan pemenuhan gizi seimbang pada remaja putri}

\section{Untuk Fasilitator}

Selalu memakai masker standar dengan benar (tidak menurunkan masker di dagu atau masker tidak menutupi hidung saat berbicara).

$\checkmark$ Fasilitator dapat menggunakan pelindung wajah (face shield), apabila tidak tersedia, fasilitator tetap harus ingat untuk tidak menyentuh wajah termasuk mata, hidung dan mulut.

$\checkmark$ Diusahakan fasilitator membawa perbekalan minum dan makan sendiri.

$\checkmark$ Diusahakan untuk tetap memakai masker atau menjauh dari tempat diskusi apabila fasilitator ingin makan atau minum bekal yang telah dibawa.

$\checkmark$ Saat proses diskusi, fasilitator harus tetap memakai masker dengan benar.

$\checkmark$ Fasilitator tetap harus membersihkan tangan sesudah menyentuh modul/alat peraga/alat-alat permainan.

$\checkmark$ Fasilitator harus mengatur jarak duduk antar peserta diskusi agar tidak terlalu dekat (minimal 1 meter)

$\checkmark$ Diusahakan memilih ruangan diskusi yang tidak terlalu sempit dan memiliki sirkulasi udara yang baik.

$\checkmark$ Sebisa mungkin fasilitator menghindari bersentuhan dengan peserta diskusi, seperti tidak berjabat tangan, berpelukan dan sebagainya.

$\checkmark$ Selalu melaksanakan etika batuk dan bersin dengan benar.

\section{Untuk Remaja Putri}

Meminta dengan sopan agar anggota remaja putri yang ikut dalam diskusi agar membawa dan memakai masker dengan benar selama kegiatan berlangsung.

$\checkmark$ Memberitahu peserta diskusi dengan sopan untuk memilih tempat diskusi yang tidak terlalu sempat dan ter dapat sikulasi udara yang baik.

Meminta dengan sopan agar setiap peserta diskusi duduk dengan mengatur jarak aman (minimal 1 meter).

$\checkmark$ Memberitahukan kepada peserta diskusi untuk meminimalisir kontak fisik seperti, berjabat tangan, berpelukan dan lainnya.

$\checkmark$ Memberitahu peserta diskusi dengan sopan agar selalu mencuci tangan atau membersihkan tangan dengan hand sanitizer yang dibawa oleh fasilitator, setelah peserta diskusi memegang modul/alat peraga/ alat-alat permainan.

$\checkmark$ Memberitahu peserta diskusi dengan sopan mengenai etika batuk dan bersin selama proses diskusi ber langsung.

Memberitahukan peserta diskusi dengan sopan agar sebisa mungkin selalu menggunakan masker apabila ingin makan dan minum, atau men jauh dari tempat diskusi beberapa saat. 


\section{LAMPIRAN}




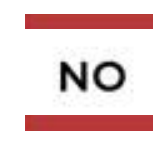

1

\section{ZAT GIZI}

Karbohidrat

Protein

\section{SUMBER BAHAN PANGAN}

Beras, jagung, umbi-umbian (ubi jalar, singkong), kentang, keladi dll

\section{Pangan hewani:}

- Daging merah, daging ayam susu, telur, ikan, udang atau pangan hewani laut lainnya Pangan nabati

- Tempe, tahu

\section{FUNGSI}

- Sebagai sumber energi utama

- Cadangan energi dalam otot dan hati

- Memperlancar pencernaan

- Sebagai pemanis alami

- Membentuk dan memperbaiki sel, serta jaringan tubuh yang rusak

- Membantu meningkatkan system kekebalan tubuh

- Membuat enzim yang memfasilitasi reaksi biokimia (mengikat hemoglobin, serta mengangkut oksigen melalui darah)

- Sebagai cadangan dan sumber energi tubuh

- Pelindung tubuh dari suhu rendah (dingin) - Pelarut vitamin A, D, E dan K

- Penghasil energi

- Penahan rasa lapar (karena adanya lemak yang memperlambat pencernaan)

- Sebagai pelindung alat tubuh vital (jantung dan lambung)

- Menjaga kesehatan mata

- Menjaga daya tahan tubuh

- Menjaga kesehatan kulit

- Sebagai antioksidan
- Sayuran berdaun hijau seperti bay

- Buah-buahan seperti melon, mangga, pepaya, semangka, dan tomat

- Umbi-umbian berwarna seperti labu kuning Pangan Hewani (Hewan)

- Susu dan produk susu, kuning telur, dan ikan

\section{- Daging susu ikar}

- Kelapa, kacang tanah, kedelai dll 


\begin{tabular}{|c|c|c|}
\hline NO & ZAT GIZI & SUMBER BAHAN PANGAN \\
\hline 5 & Vitamin D & $\begin{array}{l}\text { Pangan Hewani (Hewan) } \\
\text { - Ikan, telur, susu dan produk olahannya } \\
\text { Sinar matahari }\end{array}$ \\
\hline 6 & Vitamin $\mathrm{E}$ & $\begin{array}{l}\text { Pangan Nabati (Tumbuhan) } \\
\text { - Sayuran seperti kecambah dan brokoli } \\
\text { - Buah-buahan seperti alpukat } \\
\text { - Biji-bijian/kacang-kacangan } \\
\text { - Minyak sayur }\end{array}$ \\
\hline 7 & Vitamin $\mathrm{K}$ & $\begin{array}{l}\text { Pangan Nabati (Tumbuhan) } \\
\text { - Sayuran seperti brokoli, sawi hijau, kembang } \\
\text { kol } \\
\text { - Kedelai dan olahannya }\end{array}$ \\
\hline 8 & Vitamin C & $\begin{array}{l}\text { Pangan Nabati (Tumbuhan) } \\
\text { - Sayuran seperti brokoli, kol dan kembang kol, } \\
\text { paprika } \\
\text { - Buah-buahan seperti jeruk, jambu biji, tomat }\end{array}$ \\
\hline 9 & & $\begin{array}{l}\text { Pangan Nabati (Tumbuhan) } \\
\text { - Kacang-kacangan } \\
\text { - Beras, gandum } \\
\text { Pangan Hewani (Hewan) } \\
\text { - Telur }\end{array}$ \\
\hline
\end{tabular}

\section{FUNGSI}

- Membantu metabolisme kalsium yang sangat bermanfaat dalam proses pembentukan dan menjaga kesehatan tulang.

- Menjaga dan meningkatkan daya tahan tubuh

- Sebagai antioksidan yang mencegah kerusakan sel akibat radikal bebas

- Membantu pembekuan darah saat luka

- Menjaga daya tahan tubuh

- Sebagai antioksidan

- Menjaga daya tahan tubuh

- Membantu penyerapan zat besi di dalam tubuh

- Membantu metabolisme karbohidrat menjadi energi

- Menjaga kesehatan syaraf tepi 


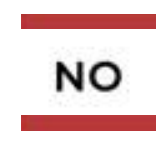

10

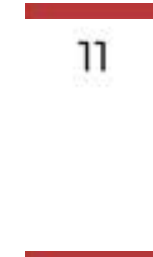

12

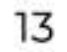

14
ZAT GIZI

Vitamin B2

Vitamin B3

Vitamin B5

Vitamin B6
SUMBER BAHAN PANGAN

Pangan Hewani (Hewan)

- Telur, susu, daging ayam, susu

Pangan Nabati (Tumbuhan)

- Asparagus

\section{Pangan Hewani (Hewan) \\ - Ikan dan daging ayam \\ Pangan Nabati (Tumbuhan) \\ - Gandum}

Pangan Hewani (Hewan)

- Daging merah dan susu

Pangan Nabati (Tumbuhan)

- Sayuran hijau dan kacang hijau

\section{Pangan Hewani (Hewan)}

- Daging sapi/kambing dan daging ayam

Pangan Nabati (Tumbuhan)

- Buah-buahan seperti pisang

- Biji-bijian dan kacang-kacangan seperti

kacang polong dan sereal

- Kentang

Vitamin B12

\section{Pangan Hewani (Hewan)}

- Daging babi, hati sapi, hati/daging ayam, daging bebek dan ikan (terutama salmon)

\section{FUNGSI}

- Membantu pembentukan sel darah merah

- Membantu metabolisme karbohidrat menjadi energi

- Membantu metabolisme karbohidrat menjadi energi

- Membantu metabolisme zat gizi terutama lemak

- Menjaga komunikasi pada sistem saraf

- Membantu metabolisme asam lemak menjadi energi

- Membantu pembentukan sel darah merah

- Menjaga Kesehatan jantung

- Memelihara kesehatan sel saraf

- Membantu pembentukan sel darah merah

- Membantu proses pembentukan molekul DNA dan RNA 


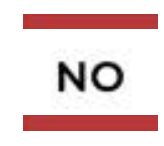

Folat

Kalsium

17

\section{Magnesium}

18

\section{SUMBER BAHAN PANGAN}

\section{Pangan Hewani (Hewan)}

- Daging ayam, telur, hati ayam

Pangan Nabati (Tumbuhan)

- Sayuran seperti bayam, asparagus, kacang panjang dan brokoli

- Buah-buahan seperti alpukat, tomat, jeruk

- Biji-bijian dan kacang-kacangan seperti gandum

\section{Pangan Nabati (Tumbuhan)}

- Sayuran seperti brokoli, bayam, pok choi

- Kacang-kacangan, kedelai, tahu dan tempe

Pangan Hewani (Hewan)

- Susu dan produk susu, berbagai jenis ikan laut, ikan teri dan kuning telur

Pangan Hewani (Hewan)
- Ikan dan makanan laut, susu dan olahannya
Pangan Nabati (Tumbuhan)
- Sayuran hijau
- Kacang-kacangan

Fosfor

\section{Pangan Hewani (Hewan)}

- Daging merah, daging ayam/bebek, ikan dan telur

Pangan Hewani (Hewan)
- Daging merah, daging ayam, ikan laut, susu
Pangan Nabati (Tumbuhan)
- Kacang-kacangan

\section{FUNGSI}

- Berperan dalam pembelahan sel pada saat pembentukan janin dalam rahim

- Membantu pembentukan sel darah merah

- Membantu proses pembentukan molekul

DNA dan RNA

- Menjaga kesehatan tulang dan gigi

- Berperan dalam kerja otot

- Berperan dalam pembekuan darah

- Berperan dalam kerja otot dan sistem saraf

- Menjaga kesehatan tulang

- Menjaga kesehatan tulang dan gigi

- Menjaga keseimbangan pH tubuh

- Menjaga daya tahan tubuh

- Berperan dalam kesehatan reproduksi

- Pembentukan hormon insulin untuk menjaga kadar gula dalam darah 


\begin{tabular}{|c|c|c|}
\hline NO & ZAT GIZI & SUMBER BAHAN PANGAN \\
\hline 20 & Besi & $\begin{array}{l}\text { Pangan Hewani (Hewan) } \\
\text { - Hati ayam, hati sapi, kerang } \\
\text { Pangan Nabati (Tumbuhan) } \\
\text { - Sayuran berdaun hijau, kedelai dan } \\
\text { olahannya }\end{array}$ \\
\hline 21 & Iodium & $\begin{array}{l}\text { Pangan Nabati (Tumbuhan) } \\
\text { - Rumput laut } \\
\text { Pangan Hewani (Hewan) } \\
\text { - Kerang, kepala ikan } \\
\text { Garam beriodium }\end{array}$ \\
\hline 22 & Kalium & $\begin{array}{l}\text { Pangan Hewani (Hewan) } \\
\text { - Yogurt } \\
\text { Pangan Nabati (Tumbuhan) } \\
\text { - Buah-buahan seperti pisang, alpukat dan } \\
\text { kurma } \\
\text { - Ubi, kacang-kacangan }\end{array}$ \\
\hline 23 & Natrium & Garam dapur, keju, saus, kecap \\
\hline
\end{tabular}

\section{FUNGSI}

- Membantu meningkatkan fungsi sel darah merah untuk mengikat oksigen dan mengedarkannya ke seluruh tubuh

- Menjaga metabolisme tubuh

- Menjaga suhu tubuh

- Komponen penting dalam perkembangan otak

- Menjaga keseimbangan osmolaritas cairan tubuh

- Menjaga keseimbangan $\mathrm{pH}$ tubuh

Berperan dalam menjaga keseimbangan cairan tubuh dan tekanan darah 
Lampiran 2. Tabel Klasifikasi Indeks Masa Tubuh untuk Remaja Putri Usia 13-19 tahun

\begin{tabular}{|c|c|c|c|c|c|c|c|c|}
\hline \multicolumn{2}{|c|}{ Umur } & \multicolumn{7}{|c|}{ Indeks Massa Tubuh (IMT) } \\
\hline Tahun & Bulan & $-3 S D$ & $-2 \mathrm{SD}$ & -1 SD & Median & +1 SD & $+2 \mathrm{SD}$ & $+3 \mathrm{SD}$ \\
\hline 13 & 2 & 13.7 & 15.0 & 16.7 & 18.9 & 22.0 & 26.4 & 33.7 \\
\hline 13 & 3 & 13.7 & 15.1 & 16.8 & 19.0 & 22.0 & 26.5 & 33.8 \\
\hline 13 & 4 & 13.8 & 15.1 & 16.8 & 19.1 & 22.1 & 26.6 & 33.9 \\
\hline 13 & 5 & 13.8 & 15.2 & 16.9 & 19.1 & 22.2 & 26.7 & 34.0 \\
\hline 13 & 6 & 13.8 & 15.2 & 16.9 & 19.2 & 22.3 & 26.8 & 34.1 \\
\hline 13 & 7 & 13.9 & 15.2 & 17.0 & 19.3 & 22.4 & 26.9 & 34.2 \\
\hline 13 & 8 & 13.9 & 15.3 & 17.0 & 19.3 & 22.4 & 27.0 & 34.3 \\
\hline 13 & 9 & 13.9 & 15.3 & 17.1 & 19.4 & 22.5 & 27.1 & 34.4 \\
\hline 13 & 10 & 14.0 & 15.4 & 17.1 & 19.4 & 22.6 & 27.1 & 34.5 \\
\hline 13 & 11 & 14.0 & 15.4 & 17.2 & 19.5 & 22.7 & 27.2 & 34.6 \\
\hline 14 & 0 & 14.0 & 15.4 & 17.2 & 19.6 & 22.7 & 27.3 & 34.7 \\
\hline 14 & 1 & 14.1 & 15.5 & 17.3 & 19.6 & 22.8 & 27.4 & 34.7 \\
\hline 14 & 2 & 14.1 & 15.5 & 17.3 & 19.7 & 22.9 & 27.5 & 34.8 \\
\hline 14 & 3 & 14.1 & 15.6 & 17.4 & 19.7 & 22.9 & 27.6 & 34.9 \\
\hline 14 & 4 & 14.1 & 15.6 & 17.4 & 19.8 & 23.0 & 27.7 & 35.0 \\
\hline 14 & 5 & 14.2 & 15.6 & 17.5 & 19.9 & 23.1 & 27.7 & 35.1 \\
\hline 14 & 6 & 14.2 & 15.7 & 17.5 & 19.9 & 23.1 & 27.8 & 35.1 \\
\hline 14 & 7 & 14.2 & 15.7 & 17.6 & 20.0 & 23.2 & 27.9 & 35.2 \\
\hline 14 & 8 & 14.3 & 15.7 & 17.6 & 20.0 & 23.3 & 28.0 & 35.3 \\
\hline 14 & 9 & 14.3 & 15.8 & 17.6 & 20.1 & 23.3 & 28.0 & 35.4 \\
\hline 14 & 10 & 14.3 & 15.8 & 17.7 & 20.1 & 23.4 & 28.1 & 35.4 \\
\hline 14 & 11 & 14.3 & 15.8 & 17.7 & 20.2 & 23.5 & 28.2 & 35.5 \\
\hline 15 & 0 & 14.4 & 15.9 & 17.8 & 20.2 & 23.5 & 28.2 & 35.5 \\
\hline 15 & 1 & 14.4 & 15.9 & 17.8 & 20.3 & 23.6 & 28.3 & 35.6 \\
\hline 15 & 2 & 14.4 & 15.9 & 17.8 & 20.3 & 23.6 & 28.4 & 35.7 \\
\hline 15 & 3 & 14.4 & 16.0 & 17.9 & 20.4 & 23.7 & 28.4 & 35.7 \\
\hline 15 & 4 & 14.5 & 16.0 & 17.9 & 20.4 & 23.7 & 28.5 & 35.8 \\
\hline 15 & 5 & 14.5 & 16.0 & 17.9 & 20.4 & 23.8 & 28.5 & 35.8 \\
\hline 15 & 6 & 14.5 & 16.0 & 18.0 & 20.5 & 23.8 & 28.6 & 35.8 \\
\hline 15 & 7 & 14.5 & 16.1 & 18.0 & 20.5 & 23.9 & 28.6 & 35.9 \\
\hline 15 & 8 & 14.5 & 16.1 & 18.0 & 20.6 & 23.9 & 28.7 & 35.9 \\
\hline 15 & 9 & 14.5 & 16.1 & 18.1 & 20.6 & 24.0 & 28.7 & 36.0 \\
\hline 15 & 10 & 14.6 & 16.1 & 18.1 & 20.6 & 24.0 & 28.8 & 36.0 \\
\hline 15 & 11 & 14.6 & 16.2 & 18.1 & 20.7 & 24.1 & 28.8 & 36.0 \\
\hline 16 & 0 & 14.6 & 16.2 & 18.2 & 20.7 & 24.1 & 28.9 & 36.1 \\
\hline 16 & 1 & 14.6 & 16.2 & 18.2 & 20.7 & 24.1 & 28.9 & 36.1 \\
\hline 16 & 2 & 14.6 & 16.2 & 18.2 & 20.8 & 24.2 & 29.0 & 36.1 \\
\hline 16 & 3 & 14.6 & 16.2 & 18.2 & 20.8 & 24.2 & 29.0 & 36.1 \\
\hline 16 & 4 & 14.6 & 16.2 & 18.3 & 20.8 & 24.3 & 29.0 & 36.2 \\
\hline 16 & 5 & 14.6 & 16.3 & 18.3 & 20.9 & 24.3 & 29.1 & 36.2 \\
\hline 16 & 6 & 14.7 & 16.3 & 18.3 & 20.9 & 24.3 & 29.1 & 36.2 \\
\hline 16 & 7 & 14.7 & 16.3 & 18.3 & 20.9 & 24.4 & 29.1 & 36.2 \\
\hline 16 & 8 & 14.7 & 16.3 & 18.3 & 20.9 & 24.4 & 29.2 & 36.2 \\
\hline 16 & 9 & 14.7 & 16.3 & 18.4 & 21.0 & 24.4 & 29.2 & 36.3 \\
\hline 16 & 10 & 14.7 & 16.3 & 18.4 & 21.0 & 24.4 & 29.2 & 36.3 \\
\hline 16 & 11 & 14.7 & 16.3 & 18.4 & 21.0 & 24.5 & 29.3 & 36.3 \\
\hline
\end{tabular}




\begin{tabular}{|c|c|c|c|c|c|c|c|c|}
\hline \multicolumn{7}{|c|}{ Umur } & \multicolumn{7}{|c|}{ Indeks } \\
\hline Tahun & Bulan & -3 SD & -2 SD & -1 SD & Median & +1 SD & +2 SD & +3 SD \\
\hline 17 & 0 & 14.7 & 16.4 & 18.4 & 21.0 & 24.5 & 29.3 & 36.3 \\
\hline 17 & 1 & 14.7 & 16.4 & 18.4 & 21.1 & 24.5 & 29.3 & 36.3 \\
\hline 17 & 2 & 14.7 & 16.4 & 18.4 & 21.1 & 24.6 & 29.3 & 36.3 \\
\hline 17 & 3 & 14.7 & 16.4 & 18.5 & 21.1 & 24.6 & 29.4 & 36.3 \\
\hline 17 & 4 & 14.7 & 16.4 & 18.5 & 21.1 & 24.6 & 29.4 & 36.3 \\
\hline 17 & 5 & 14.7 & 16.4 & 18.5 & 21.1 & 24.6 & 29.4 & 36.3 \\
\hline 17 & 6 & 14.7 & 16.4 & 18.5 & 21.2 & 24.6 & 29.4 & 36.3 \\
\hline 17 & 7 & 14.7 & 16.4 & 18.5 & 21.2 & 24.7 & 29.4 & 36.3 \\
\hline 17 & 8 & 14.7 & 16.4 & 18.5 & 21.2 & 24.7 & 29.5 & 36.3 \\
\hline 17 & 9 & 14.7 & 16.4 & 18.5 & 21.2 & 24.7 & 29.5 & 36.3 \\
\hline 17 & 10 & 14.7 & 16.4 & 18.5 & 21.2 & 24.7 & 29.5 & 36.3 \\
\hline 17 & 11 & 14.7 & 16.4 & 18.6 & 21.2 & 24.8 & 29.5 & 36.3 \\
\hline 18 & 0 & 14.7 & 16.4 & 18.6 & 21.3 & 24.8 & 29.5 & 36.3 \\
\hline 18 & 1 & 14.7 & 16.5 & 18.6 & 21.3 & 24.8 & 29.5 & 36.3 \\
\hline 18 & 2 & 14.7 & 16.5 & 18.6 & 21.3 & 24.8 & 29.6 & 36.3 \\
\hline 18 & 3 & 14.7 & 16.5 & 18.6 & 21.3 & 24.8 & 29.6 & 36.3 \\
\hline 18 & 4 & 14.7 & 16.5 & 18.6 & 21.3 & 24.8 & 29.6 & 36.3 \\
\hline 18 & 5 & 14.7 & 16.5 & 18.6 & 21.3 & 24.9 & 29.6 & 36.2 \\
\hline 18 & 6 & 14.7 & 16.5 & 18.6 & 21.3 & 24.9 & 29.6 & 36.2 \\
\hline 18 & 7 & 14.7 & 16.5 & 18.6 & 21.4 & 24.9 & 29.6 & 36.2 \\
\hline 18 & 8 & 14.7 & 16.5 & 18.6 & 21.4 & 24.9 & 29.6 & 36.2 \\
\hline 18 & 9 & 14.7 & 16.5 & 18.7 & 21.4 & 24.9 & 29.6 & 36.2 \\
\hline 18 & 10 & 14.7 & 16.5 & 18.7 & 21.4 & 24.9 & 29.6 & 36.2 \\
\hline 18 & 11 & 14.7 & 16.5 & 18.7 & 21.4 & 25.0 & 29.7 & 36.2 \\
\hline 19 & 0 & 14.7 & 16.5 & 18.7 & 21.4 & 25.0 & 29.7 & 36.2 \\
\hline
\end{tabular}


Permasalahan gizi pada remaja merupakan salah satu permasalahan kesehatan masyarakat yang sejak lama di temukan di Desa Ban, Kabupaten Karangasem, Provinsi Bali. Intervensi untuk mengatasi permasalahan gizi pada kelompok remaja ini telah dilakukan bersamaan dengan intervensi pada kelompok rentan lainnya seperti ibu hamil, ibu baduta dan baduta. Namun intervensi yang ditawarkan masih mempunyai beberapa kelemahan seperti masih bersifat individual. Oleh karena itu perlu sebuah inovasi intervensi gizi yang menggunakan pendekatan yang inovatif dengan melibatkan peer atau teman sebaya dalam upaya mengatasi permasalahan gizi ini.

Intervensi yang dilakukan diharapkan dapat meningkatkan pengetahuan, menumbuhkan sikap positif dan merubah perilaku mengenai asupan gizi seimbang pada remaja putri. Modul ini disusun sebagai bagian dari intervensi dimaksud dengan tujuan untuk meningkatkan kemampuan dan keterampilan petugas lapangan/fasilitator dalam memberikan edukasi gizi seimbang pada remaja. Modul ini berisikan panduan-panduan dalam pemberian materi dan permainan untuk mendukung peningkatan pengetahuan, perubahan sikap dan perilaku yang positif pada remaja putri mengenai pemenuhan gizi seimbang untuk dirinya dan lingkunagn sebayanya.

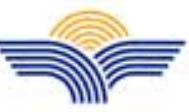

\section{PENERBIT}

PANUDUH ATMA WARAS

JI. ByPass Ngurah Rai Nomor: 888 xx, ISBN 978-623-97473-8-1 (PDF)

Denpasar, Bali - Indonesia

(0361) 6209990

$(+62) 82236180725$

info@baswarapress.com

panuduhatmawaras@gmail.com

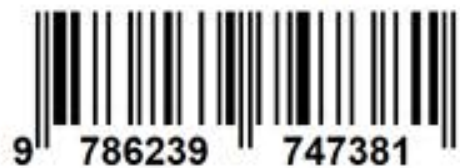

